\title{
Trends in off-channel fish habitat on the Missouri River below Fort Peck Dam: 1956-2013
}

\author{
Prepared for: \\ Montana Fish, Wildlife, and Parks \\ Region 6 Fisheries \\ Prepared by: \\ Sara Owen \\ Montana Natural Heritage Program \\ a cooperative program of the \\ Montana State Library and the University of Montana
}

December 2014

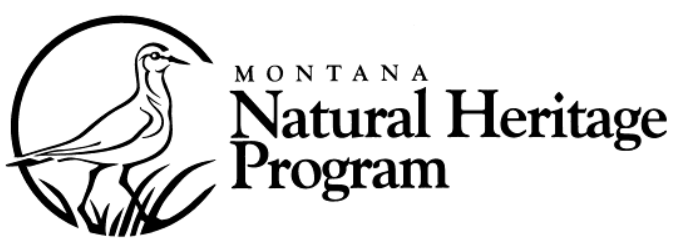




\title{
Trends in off-channel fish habitat on the Missouri River below Fort Peck dam: 1956-2013
}

Prepared for:

\author{
Montana Fish, Wildlife, and Parks \\ Region 6 Fisheries
}

Agreement Number:

140010

Prepared by:

Sara Owen
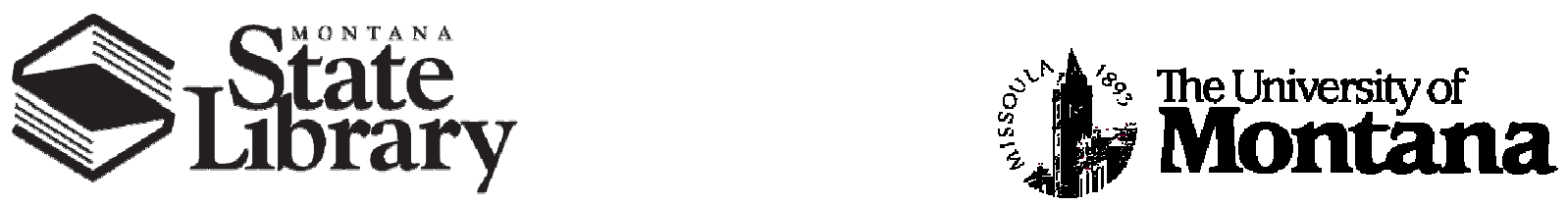

CO2014 Montana Natural Heritage Program

P.O. Box $201800 \bullet 1515$ East Sixth Avenue • Helena, MT 59620-1800 • 406-444-5354 
This document should be cited as follows:

Owen, Sara. 2014. Trends in off-channel fish habitat on the Missouri River below Fort Peck Dam: 1956-2013. Report to Montana Fish, Wildlife, and Parks. Montana Natural Heritage Program, Helena, Montana. 34 pp. 


\begin{abstract}
Off-channel habitats such as backwaters and side channels provide important nursery and feeding habitats for native fishes of the Missouri River, including the endangered pallid sturgeon (Scaphirhynchus albus). We mapped backwaters, side channels, and secondary channels (hereafter referred to as "other channels") on the Missouri River below Fort Peck dam for 1956/57, 1980, 2009, 2011, and 2013. We compared the total number of mapped features and mean length, area, and perimeter of the features between 1956/57 (hereafter referred to as 1956) and 2013 to determine if there are discernable trends in availability of off-channel habitats to native fish. Relative to 1956, 2013 had less total area of off-channel habitat available, as well as a smaller mean area, suggesting a loss of suitable habitat for the pallid sturgeon and other native fishes of the Missouri River below Fort Peck dam. The large flood event in 2011 may have scoured sediments that accumulated during low flow years of the mid-2000s, leading to channel incision and loss of connection between off-channel habitat and the main river channel.
\end{abstract}




\section{ACKNOWLEDGMENTS}

This project was funded by the Montana Fish, Wildlife, and Parks (FWP). We would like to thank Andy Brummond in the FWP Lewistown Area Resource Office for initiating this project and for his support and guidance during this process. Steve Dalbey, Dave Fuller, and Tyler Haddix in the FWP Region 6 Headquarters Office provided invaluable on-the-ground insight during data analysis. Jamul Hahn assisted with habitat mapping, GIS analysis, and figures.

Karen Newlon and Linda Vance of MTNHP provided useful comments on an earlier draft of this report. Any errors or omissions in the report are entirely the responsibility of the author. 


\section{TABLE OF CONTENTS}

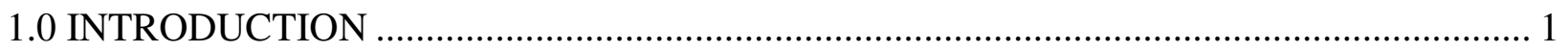

2.0 METHODS

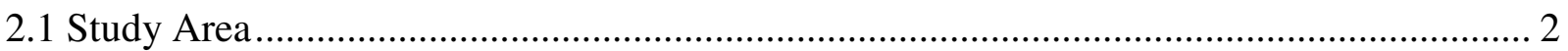

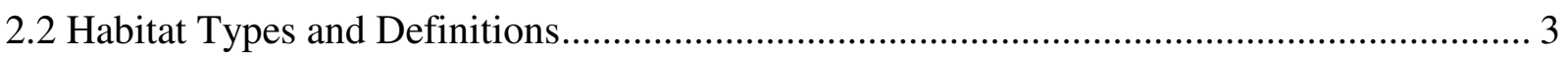

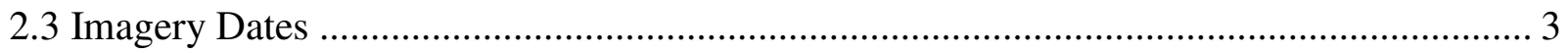

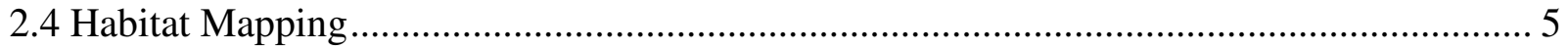

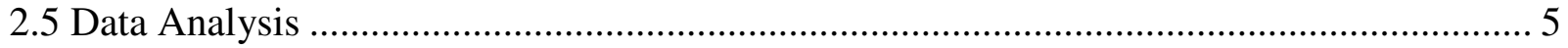

2.5.1 1956, 1980, 2009, 2013 subset ................................................................... 5

2.5.2 1956, 2009, 2013 Fort Peck dam to North Dakota state line ..................................... 5

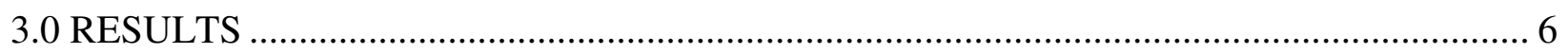

3.1 Habitat Trends 1956, 1980, 2009, 2013 subset............................................................... 6

3.2 Habitat Trends 1956, 2009, 2013 Fort Peck dam to North Dakota state line ..................... 10

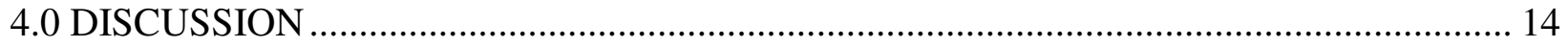

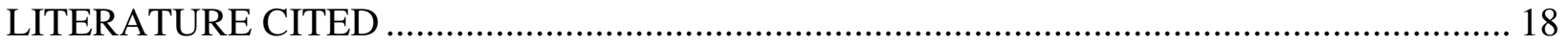

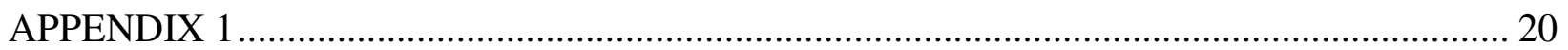

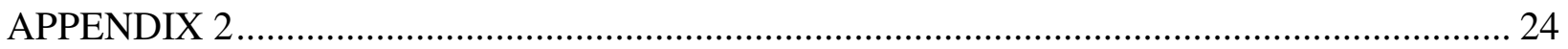




\section{LIST OF TABLES}

Table 1. The number, length, area, and perimeter of off-channel aquatic habitats approximately $165 \mathrm{~km}$ below Fort Peck dam using 1956, 1980, 2009, and 2013 aerial imagery ...................... 7

Table 2. Relative changes in the number, length, area, and perimter of habitat features approximately $165 \mathrm{~km}$ downstream of Fort Peck dam 1956-2013.

Table 3. The number, length, area, and perimeter of off-channel aquatic habitats to the North Dakota state line using 1956, 2009, and 2013 aerial imagery........................................... 11

Table 4. Relative changes in the number, length, area, and perimeter of habitat features to the North Dakota state line 1956-2013

\section{LIST OF FIGURES}

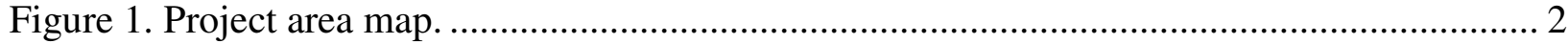

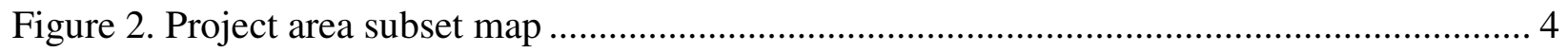

Figure 3. Hydrograph of mean daily discharge on the Missouri River. ................................... 4

Figure 4. Off-channel habitat features culled from analysis............................................... 6

Figure 5. Mean length of habitat features approximately $165 \mathrm{~km}$ below Fort Peck dam............. 8

Figure 6. Mean perimeter of habitat features approximately $165 \mathrm{~km}$ below Fort Peck dam ........ 8

Figure 7. Mean area of habitat features approximately $165 \mathrm{~km}$ below Fort Peck dam ................ 9

Figure 8. Proportion of habitat features approximately $165 \mathrm{~km}$ below Fort Peck dam.............. 10

Figure 9. Mean length of habitat features to the North Dakota state line ................................ 12

Figure 10. Mean perimeter of habitat features to the North Dakota state line........................... 12

Figure 11. Mean area of habitat features to the North Dakota state line .................................. 13

Figure 12. Proportion of habitat features to the North Dakota state line ................................. 14

Figure 13. Milk River entering the Missouri River ........................................................... 15

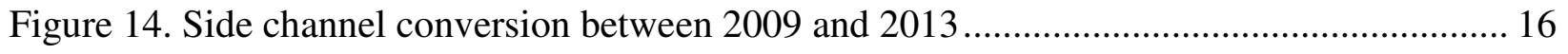




\subsection{INTRODUCTION}

Prior to regulation, the Missouri River was a multichannel system consisting of a primary channel and often many secondary channels. River bank erosion and lateral migration of the river channel were processes that played an important ecological role in maintaining a diverse landscape of sandbars, islands, sloughs, backwaters, oxbow lakes, and meander loops (National Research Council 2011). These processes were most prominent during flood events, as overbank flows, bank erosion, and channel avulsions allowed for the redistribution of sediment between the river channel and its floodplain, a key component in maintaining the diversity of floodplain habitats (Dryer and Sandvol 1993, Ward and Stanford 1995, Shields, Jr. et al 2000, National Research Council 2011). Some off-channel habitats, like abandoned channels and oxbow lakes, may be connected to the main river channel only during flooding. Other off-channel habitats, like backwaters and side channels, remain connected to the main channel during base flows and serve as habitat for fish and other aquatic fauna throughout the year. These habitats are characterized by shallow, slow moving water with higher water temperatures than the main channel, and silt-dominated substrates (Sheaffer and Nickum 1986). Backwaters and side channels provide important shallow water spawning and nursery habitats to the native fishes of the Missouri River downstream of Fort Peck dam (Dryer and Sandvol 1993). These habitats provide important benefits to aquatic ecosystems such as spawning and nursery grounds for fish (Whitley and Campbell 1974, Sheaffer and Nickum 1986, Sedell et al. 1990, Yager et al. 2011), refuge from predators, protection from high river discharge, particularly during flood events (Sedell 1990, Yager et al. 2013), and increased macroinvertebrate production and density compared to the main river channel (Whitley and Campbell 1974, Sheaffer and Nickum 1986, Yager et al. 2013). In addition, backwater habitats may have an abundance of woody debris that provides important foraging and spawning sites (Ward and Stanford 1995, Lehtinen et al. 1997).

Sediment-rich prairie rivers, like the Missouri River, are characterized by turbid and relatively shallow warm waters with unstable sand-silt substrates and abundant large woody debris snags (National Research Council 2011). Efforts to alter the Missouri River for navigation purposes began in the early $19^{\text {th }}$ century and included practices such as snag removal, dredging, and diking, which aimed to deepen the channel and stabilize the river banks (Blevins 2006). In the early 1930s, construction began on Fort Peck dam in Montana. Construction of the dam was completed in 1937, setting the stage for drastic changes in river hydrology and morphology due to a loss of peak flows in spring and early summer as well as a reduction in the amount of sediment passing downstream of the dam. Sediment-starved waters released from reservoirs can lead to channel incision and bed degradation downstream of dams (Ward and Stanford 1995, Shields, Jr. et al 2000, National Research Council 2011). Once channel incision begins, large floodplain rivers become disconnected from their floodplains, leading to a lowered water table and a loss of channel migration events that once maintained a diverse floodplain habitat (Bayley 1995, Ligon et al 1995, Shields, Jr. et al. 2000, Yager et al. 2011). Changes in river hydrology and morphology due to anthropogenic disturbances, primarily the construction of large dams, channelization, and diking, on the Missouri River are believed to have led to the decline of the pallid sturgeon (Scaphirhynchus albus) from historic numbers (Dryer and Sandvol 1993, Webb et al 2005). Consequently, the pallid sturgeon was added to the endangered species list in 1990 (Dryer and Sandvol 1993). 
This study is a follow up to our original study (Owen and Hahn 2014) modeled after Yager et al. (2011) who examined changes in backwater and side channel habitats on the Missouri River in South Dakota. These studies attempt to determine if the Missouri River still has adequate suitable habitat to prevent the extirpation of the pallid sturgeon. The objective of this study was to evaluate trends in the relative quantity of side channel and backwater habitats on approximately 300 kilometers ( 185 miles) of the Missouri River downstream of Fort Peck dam between 1956 and 2013. The results are expected to aid fisheries biologists in directing pallid sturgeon recovery efforts and native fish management along with the related operations of Fort Peck dam.

\subsection{METHODS}

\subsection{Study Area}

The project study area encompasses approximately 300 kilometers of the Missouri River between Fort Peck dam and the North Dakota state line (Figure 1). Fort Peck dam was the first of six main stem dams built on the Missouri River by the 1960s (Yager et al. 2011). The Pallid Sturgeon Recovery Plan (Dryer and Sandvol 1993) identifies this segment of the Missouri River as one of six recovery-priority management areas based on recent records of pallid sturgeon occurrence and the probability that these areas still provide suitable habitat for pallid sturgeon. The recovery-priority areas are viewed as the most suitable segments of river to employ restoration and recovery efforts because they are typically the least degraded and have the highest habitat diversity.

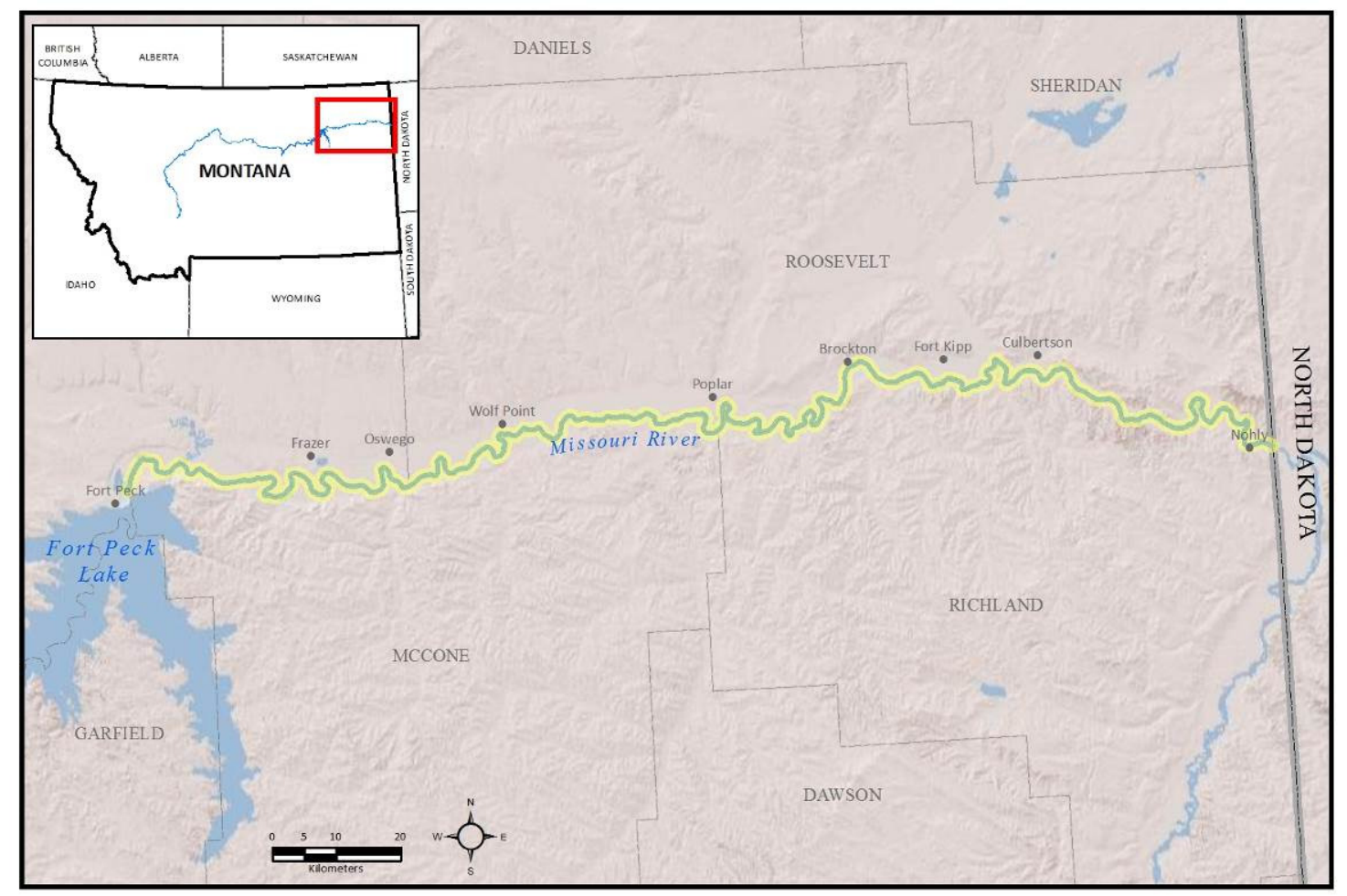

Figure 1. Trends in off-channel habitats were analyzed along the Missouri River from below Fort Peck dam downstream to the North Dakota state line. 


\subsection{Habitat Types and Definitions}

We identified and delineated three habitat types: backwaters, side channels, and other channels, which are described in detail in Owen and Hahn (2014) but brief definitions are included here. Backwaters were typically defined as bodies of water with only a downstream connection to the main river channel and no upstream connection during baseline flows (Yager et al. 2011). Side channels were defined as flowing off-channel habitats (30m wide or less) with both an upstream and downstream connection to the main river channel. Other channels were defined as secondary channels that were wider than $30 \mathrm{~m}$ but were not considered to be a main channel with high discharge.

\subsection{Imagery Dates}

We analyzed imagery for four dates: 1956/1957 (for simplicity this will be referred to as 1956 for the remainder of the report), 1980, 2009, and 2013. The imagery selected for analysis was limited by water level. Instances where water levels were too high in the imagery would obscure features that would normally be visible in lower water years, so every effort was made to limit the range to have as little variability as possible. Water level ranges are reported as discharge (cubic feet per second, CFS) from the Wolf Point gauge (USGS Station 06177000). Our ideal range of discharge was 5,000 - 8,300 CFS (Andy Brummond, MT Fish, Wildlife, and Parks). For the 1956 image date, we acquired historic black and white imagery (U.S. Department of Agriculture) that was flown between 8/1 - 11/26/1956 and 6/23 - 9/26/1957. During this period, the discharge ranged from 5,400 - 10,500 CFS. For the 1980 image date, black and white imagery from 5/14/1980 (U.S. Department of Agriculture) was acquired for approximately 165 $\mathrm{km}$ below Fort Peck dam (Figure 2). Discharge on this date was 7,000 CFS. For the rest of the river downstream to the North Dakota state line, discharge ranged from 9,900 - 13,500 CFS, which was determined to be too high for the objectives of this study. Color infrared (CIR) imagery (National Agricultural Imagery Program) was acquired for 2009 and 2013. The 2009 imagery was flown between 7/11 - 7/23/2009, and discharge ranged from 6,650 - 6,700 CFS for those dates. The 2013 imagery was flown between 7/3 - 7/27/2013, and discharge ranged from 7,900 - 11,000 CFS for those dates.

There is some discrepancy in the ranges of water levels between years, where the discharge is higher for some years than others. The imagery with these higher water levels covered small areas of the river and these areas often were not the same between years. Thus, we used imagery for the entire river from 1956, 2009, and 2013. These years are analyzed as one set of data. We incorporated the 1980 imagery into our analysis along with the other years and used that subset of data for $165 \mathrm{~km}$ below Fort Peck dam as a separate analysis.

The 1956 imagery was flown nearly 20 years after the closure of Fort Peck dam. Initially there was some question whether this imagery was old enough to capture a historic view of the river before the effects of flow regulation began to change the river morphology. A hydrograph of mean daily discharge at the Wolf Point USGS gauge shows that peak flows on the river were not suppressed until around 1955, when Lake Sakakawea filled approximately $500 \mathrm{~km}$ downstream 
in North Dakota (Figure 3). This suggests that the historic imagery provides an accurate depiction of river conditions prior to regulation.

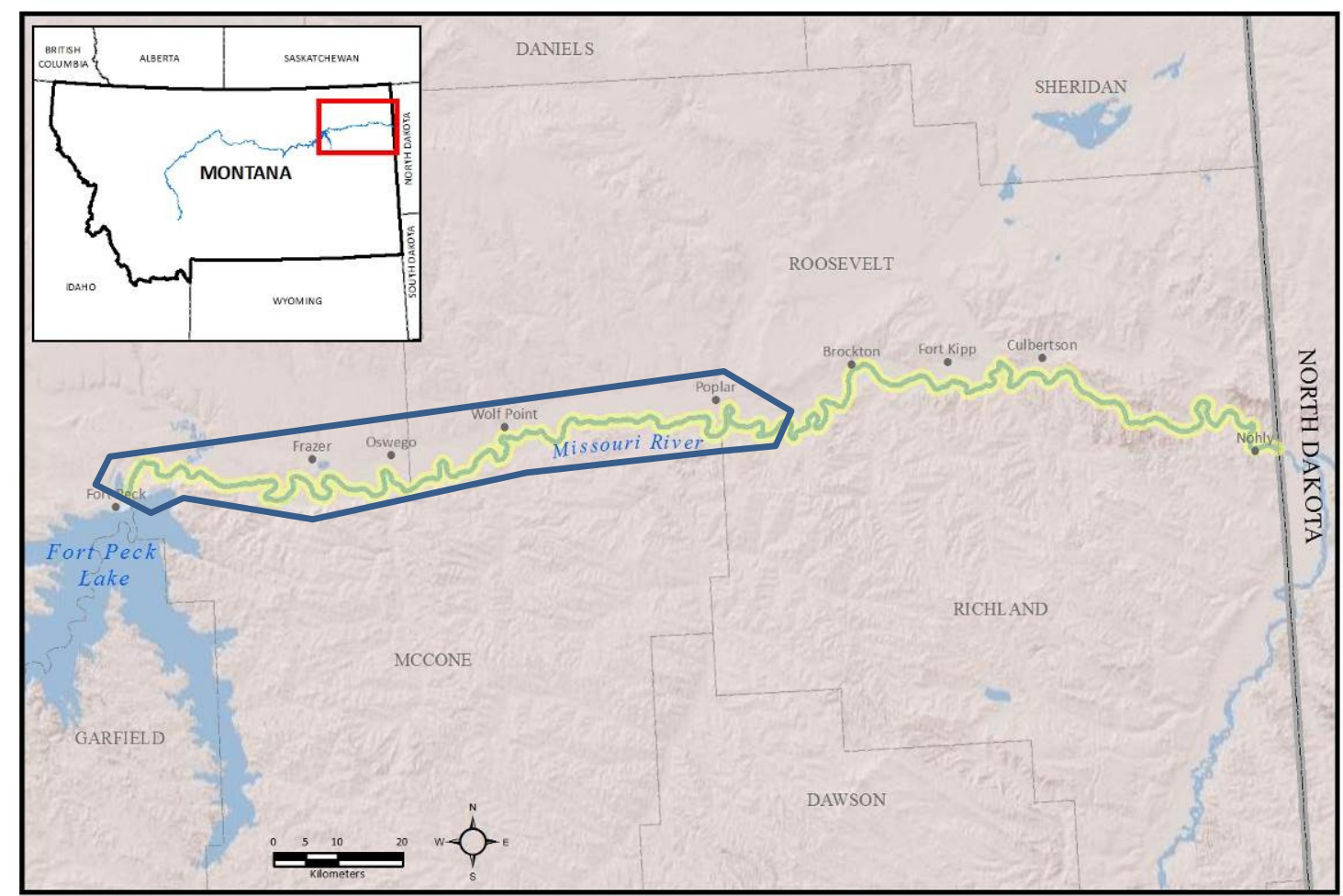

Figure 2. The subset analysis for trends in off-channel habitat includes approximately $165 \mathrm{~km}$ of the Missouri River below Fort Peck dam.

Imagery for 2011 was not included in this analysis because discharge ranged from 35,500 47,000 CFS for the dates the imagery was flown. This range of discharge, as shown in Figure 3, is many times higher than the average range of discharge seen on the Missouri River since the mid-1950s. As noted in Owen and Hahn (2014), much of the available off-channel habitat and floodplain were inundated during this flood event, so the data are not comparable to the remaining years included in the analysis.

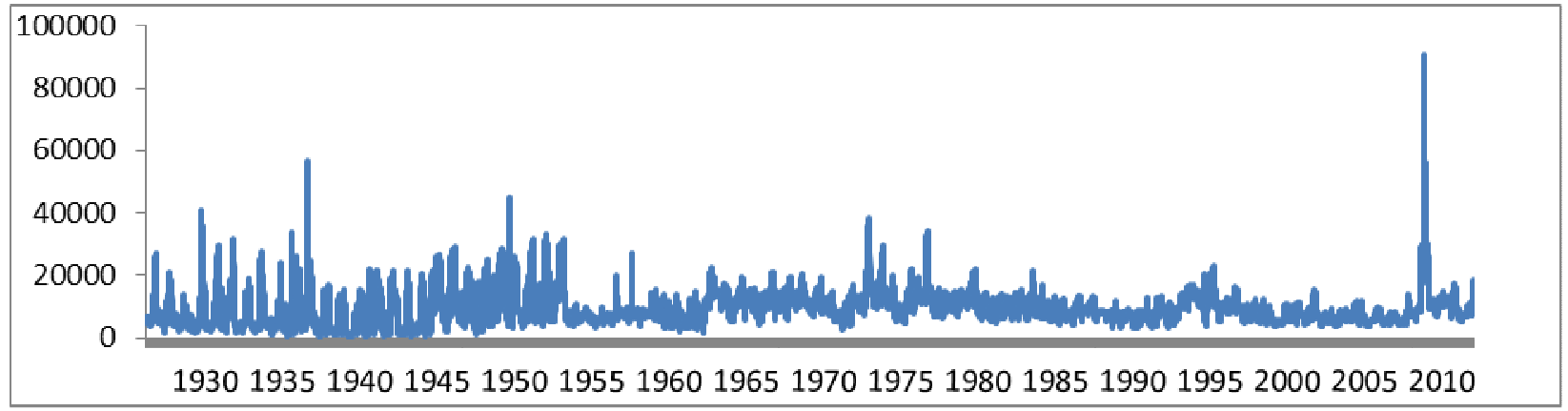

Figure 3. Hydrograph of mean daily discharge on the Missouri River at the Wolf Point gauge from October 1928 through August 2014. 


\subsection{Habitat Mapping}

We georeferenced imagery from 1956 and 1980 using ESRI® ArcMap 10.2 software. Each image was orthorectified and aligned to the Montana 2009 NAIP imagery and projected into the NAD 83 Montana State Plane coordinate system. A first-order polynomial transformation using three control points was used to link and align the historical photography with the spatially referenced 2009 NAIP imagery. Control points used include street and road intersections, bridge locations, rock outcrops, corners of established fields, building corners and occasionally, large cottonwood trees.

All recognizable off-channel habitats (backwaters, side channels, and other channels) were interpreted from the imagery and digitized as polygon features in a geodatabase using ArcMap 10.2. We mapped all features at a scale of 1:4,000. We calculated the area, length, and perimeter of each off-channel habitat feature in ArcMap. In cases where water was shallow over sand, it was difficult to determine if there was a connection to the main channel; we tended to map conservatively for these questionable areas.

\subsection{Data Analysis}

\subsubsection{6, 1980, 2009, 2013 subset}

We tested for significant differences in mean characteristics of the off-channel habitats (area, perimeter, and length) between the 1956, 1980, 2009 and 2013 image years using a single-factor analysis of variance (ANOVA) with a Tukey post hoc test for multiple comparisons between years. All calculations were done in Microsoft Excel ${ }^{\circledR}$ Analysis ToolPak (Microsoft Corporation, Redmond, Washington). For all statistical tests, p-values $\leq 0.05$ were considered statistically significant.

With input from FWP, we removed one very large other channel located immediately below Fort Peck dam from this data set. This feature is much larger than the rest of the other channels and it is not of the same character as the rest of the data (Figure $4 a$ ). This feature is approximately 60 ha, which is many times larger than the next largest off-channel habitat feature.

\subsubsection{6, 2009, 2013 Fort Peck dam to North Dakota state line}

We tested for significant differences in mean characteristics of the off-channel habitats (area, perimeter, and length) between the 1956, 2009 and 2013 image years using a single-factor ANOVA with a Tukey post hoc test for multiple comparisons between years. All calculations were done in Microsoft Excel ${ }^{\circledR}$ Analysis ToolPak (Microsoft Corporation, Redmond, Washington). For all statistical tests, $p$-values $\leq 0.05$ were considered statistically significant.

We removed two very large features for this data analysis: the other channel below Fort Peck dam and a large backwater (Figure 4b) that formed as a meander cutoff sometime between 1956 and 2009. Due to its uncharacteristically large size relative to all other backwaters, we decided to cull this feature so as not to skew the data analysis. 


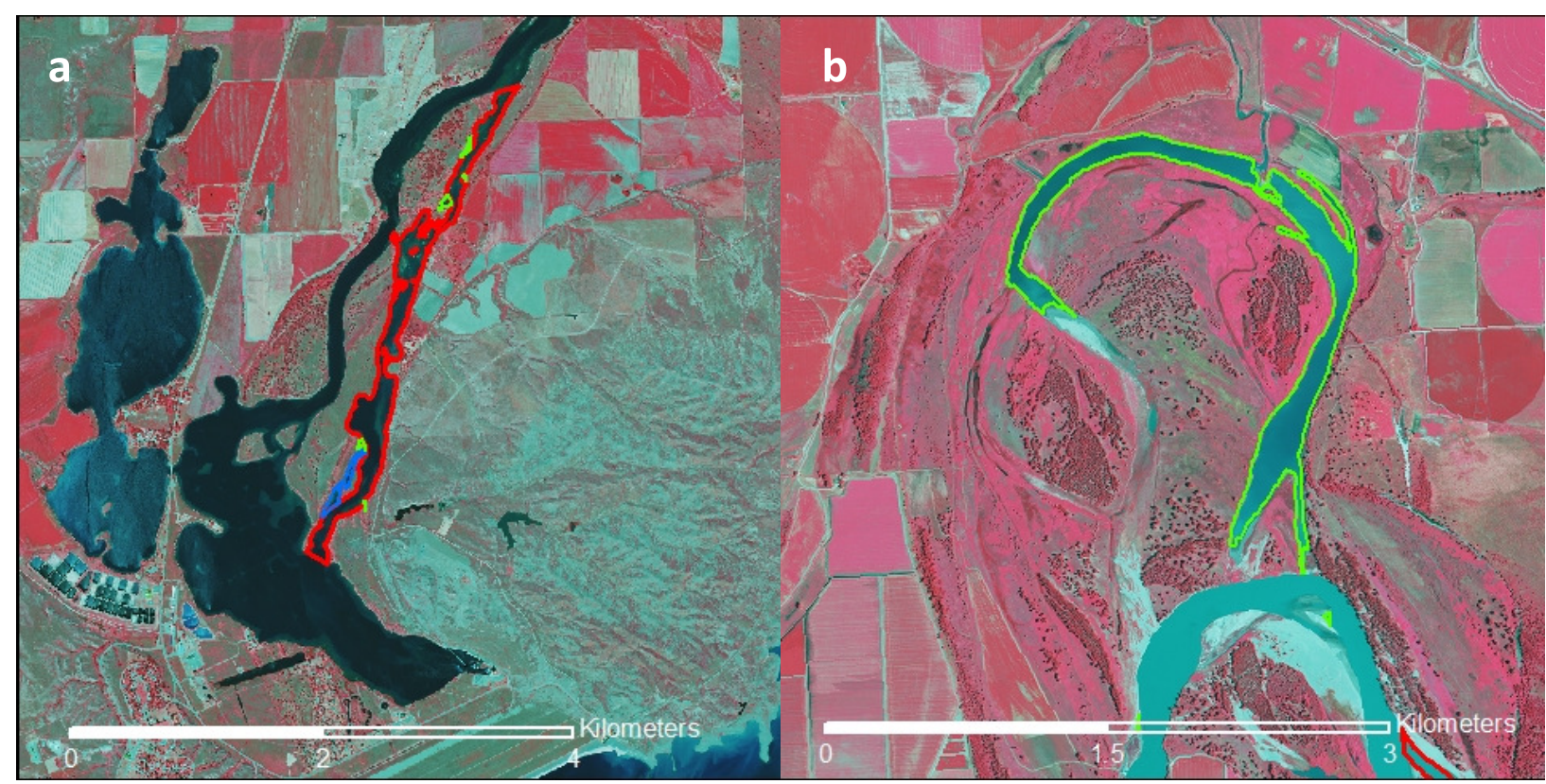

Figure 4. A large other channel (red) immediately below Fort Peck dam (a) and a large backwater (green) (b) that formed from a channel meander cutoff were culled from the data analysis due to their uncharacteristic size relative to the other mapped off-channel habitat features.

\subsection{RESULTS}

\subsubsection{Habitat trends: 1956, 1980, 2009, 2013 subset}

In general, the number of off-channel habitat features increased between 1956 and 2009, then declined in 2013 (Table 1). Between 1956 and 2013, the number of side channels and other channels decreased by $43 \%$ and $26 \%$, respectively, whereas the number of backwaters increased by $16 \%$ (Table 2). The total number of all habitat features was unchanged between 1956 and 2013 (a 1\% increase in 2013, Table 2).

There was a significant decline in mean length and mean area of backwaters between 1956 and 2013 (Figures 5 \& 7) but no significant difference for mean perimeter (Figure 6). There were no significant differences in mean length, perimeter, or area for backwaters between 1956 and 2013; however, side channels saw the greatest loss of total length, perimeter, and area during this time period, ranging from $61-76 \%$ (Table 2). Other channels were significantly different in 2009 than all other years for mean length, perimeter, and area. When all features were combined, mean length, perimeter, and area declined over time, and 2013 values were significantly smaller than 1956 values (Figures 5-7, Appendix 1).

We observed a shift in the relative and absolute number of mapped habitat features between 1956 and 2013. The proportion of mapped habitats appears to be shifting towards more backwaters and fewer side channels and other channels (Figure 8). Backwaters increased from 64.5\% of mapped features in 1956 to over 75\% of mapped off-channel features in 2013. 
Table 1. The number, length, area, and perimeter of off-channel aquatic habitats mapped from Fort Peck dam downstream approximately $165 \mathrm{~km}$ using 1956, 1980, 2009, and 2013 aerial imagery.

\begin{tabular}{|c|c|c|c|c|c|c|c|c|}
\hline $\begin{array}{c}\text { Imagery } \\
\text { Date }\end{array}$ & Feature Type & $\begin{array}{c}\text { Total } \\
\text { Number }\end{array}$ & $\begin{array}{c}\text { Total Length } \\
(\mathrm{m})\end{array}$ & $\begin{array}{l}\text { Mean Length } \\
(\mathrm{m})\end{array}$ & $\begin{array}{c}\text { Total Area } \\
\text { (ha) }\end{array}$ & $\begin{array}{c}\text { Mean Area } \\
\text { (ha) }\end{array}$ & $\begin{array}{c}\text { Total Perimeter } \\
(\mathrm{m})\end{array}$ & $\begin{array}{c}\text { Mean } \\
\text { Perimeter }(m)\end{array}$ \\
\hline \multirow[t]{4}{*}{1956} & Backwater & 151 & $31,229.75$ & $206.82(20.54)$ & 78.01 & $0.52(0.08)$ & $70,542.19$ & 467.17 (49.17) \\
\hline & Side channel & 14 & $12,423.30$ & $887.38(143.20)$ & 44.15 & $3.15(0.85)$ & $31,470.09$ & $2,247.86(437.33)$ \\
\hline & Other channel & 69 & $42,986.49$ & $622.99(69.70)$ & 241.36 & $3.50(0.64)$ & $103,961.86$ & $1,506.69(177.42)$ \\
\hline & ALL FEATURES & 234 & $86,639.54$ & $370.25(29.75)$ & 363.52 & $1.55(0.22)$ & $205,974.14$ & $880.23(76.16)$ \\
\hline \multirow[t]{4}{*}{1980} & Backwater & 225 & $37,197.07$ & $165.32(10.35)$ & 77.16 & $0.34(0.03)$ & $86,965.93$ & $386.52(26.80)$ \\
\hline & Side Channel & 12 & $11,289.32$ & $940.78(125.32)$ & 41.35 & $3.45(0.72)$ & $28,961.89$ & $2,413.49$ (311.81) \\
\hline & Other Channel & 98 & $57,931.04$ & $591.13(38.65)$ & 297.21 & $3.03(0.32)$ & $148,612.07$ & $1,516.45(109.36)$ \\
\hline & ALL FEATURES & 335 & $106,417.42$ & $317.66(18.64)$ & 415.72 & $1.24(0.12)$ & $264,539.89$ & 789.67 (50.27) \\
\hline \multirow[t]{4}{*}{2009} & Backwater & 217 & $26,300.92$ & $121.20(6.48)$ & 39.83 & $0.18(0.02)$ & $61,791.66$ & $284.75(15.55)$ \\
\hline & Side channel & 57 & $34,915.54$ & $612.55(46.59)$ & 79.13 & $1.38(0.17)$ & $87,860.79$ & $1,541.42(122.39)$ \\
\hline & Other channel & 176 & $61,910.12$ & $351.76(23.79)$ & 238.79 & $1.36(0.15)$ & $161,629.41$ & 918.35 (64.92) \\
\hline & ALL FEATURES & 450 & $123,126.57$ & $273.61(13.89)$ & 357.76 & $0.80(0.07)$ & $311,281.86$ & $691.74(36.90)$ \\
\hline \multirow[t]{4}{*}{2013} & Backwater & 178 & $28,065.37$ & $157.67(11.00)$ & 56.59 & $0.32(0.04)$ & $63,568.96$ & $357.13(24.96)$ \\
\hline & Side channel & 8 & $4,850.24$ & $606.28(144.33)$ & 10.59 & $1.32(0.46)$ & $11,916.37$ & $1,489.55$ (339.35) \\
\hline & Other channel & 51 & $29,858.70$ & $585.46(48.40)$ & 131.66 & $2.58(0.35)$ & $69,861.29$ & $1,369.83(119.57)$ \\
\hline & ALL FEATURES & 237 & $62,774.30$ & $264.87(18.51)$ & 198.84 & $0.84(0.10)$ & $145,346.62$ & $613.28(44.26)$ \\
\hline
\end{tabular}

For means, standard errors are reported in parentheses. 


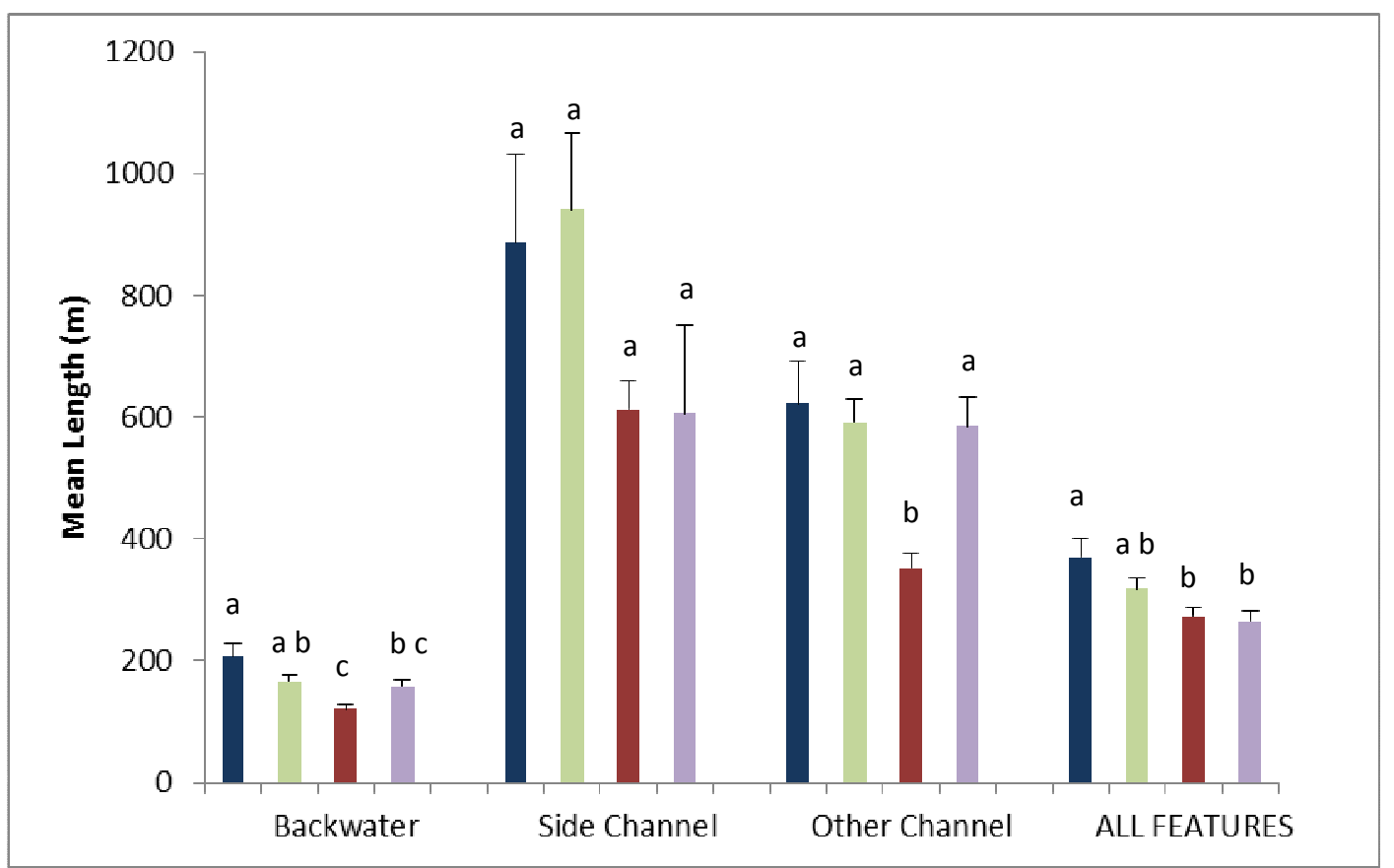

Figure 5. Mean length of off-channel habitat features mapped on the Missouri River approximately $165 \mathrm{~km}$ below Fort Peck dam. Numbers are presented in chronological order from left to right: dark blue bars are 1956, green bars are 1980, red bars are 2009, and purple bars are 2013. Letters designate significant differences between years.

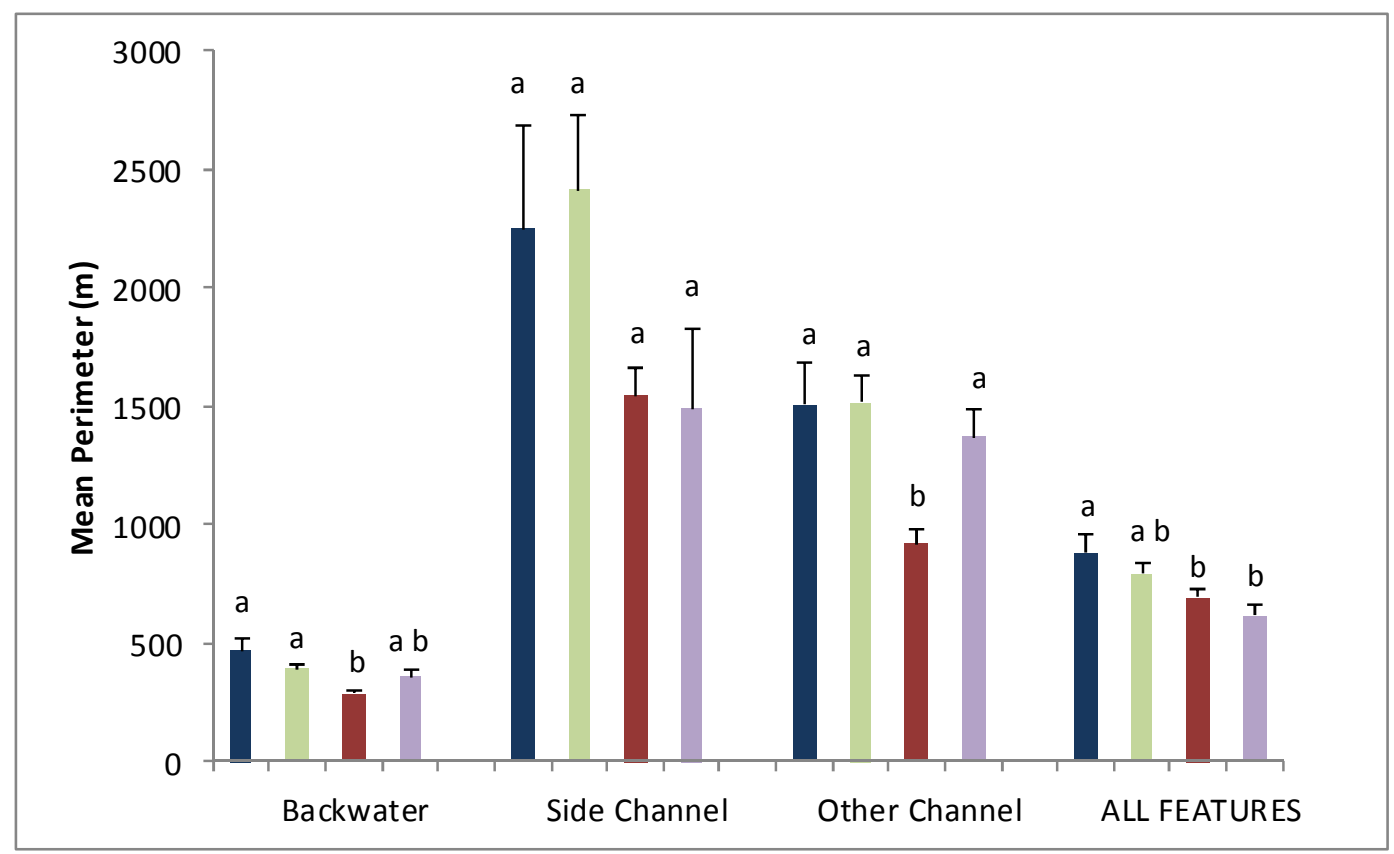

Figure 6. Mean perimeter of off-channel habitat features mapped on the Missouri River approximately $165 \mathrm{~km}$ below Fort Peck dam. Numbers are presented in chronological order from left to right: dark blue bars are 1956, green bars are 1980, red bars are 2009, and purple bars are 2013. Letters designate significant differences between years. 


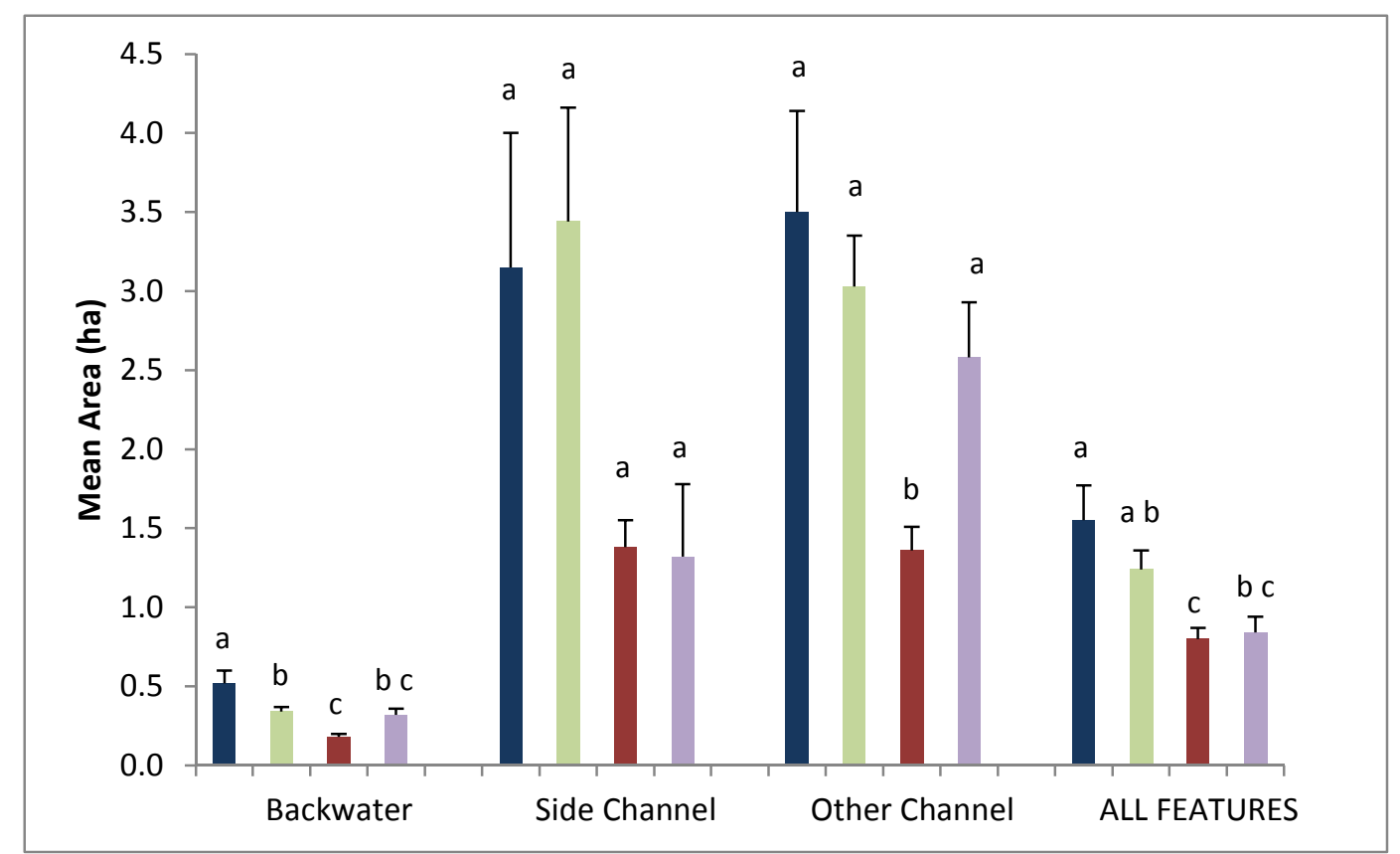

Figure 7. Mean area of off-channel habitat features mapped on the Missouri River approximately $165 \mathrm{~km}$ below Fort Peck dam. Numbers are presented in chronological order from left to right: dark blue bars are 1956, green bars are 1980, red bars are 2009, and purple bars are 2013. Letters designate significant differences between years.

Table 2. Relative changes in the number, length, area, and perimeter of habitat features between 1956 and 2013 from Fort Peck dam downstream approximately 165 km.

\begin{tabular}{l|ccccccc} 
& $\begin{array}{c}\text { Number } \\
\text { of } \\
\text { Features }\end{array}$ & $\begin{array}{c}\text { Total } \\
\text { Length }\end{array}$ & $\begin{array}{c}\text { Mean } \\
\text { Length }\end{array}$ & $\begin{array}{c}\text { Total } \\
\text { Area }\end{array}$ & $\begin{array}{c}\text { Mean } \\
\text { Area }\end{array}$ & $\begin{array}{c}\text { Total } \\
\text { Perimeter }\end{array}$ & $\begin{array}{c}\text { Mean } \\
\text { Perimeter }\end{array}$ \\
\hline Backwater & $16 \%$ & $-10 \%$ & $-24 \%$ & $-27 \%$ & $-38 \%$ & $-10 \%$ & $-24 \%$ \\
Side Channel & $-43 \%$ & $-61 \%$ & $-32 \%$ & $-76 \%$ & $-58 \%$ & $-62 \%$ & $-34 \%$ \\
Other Channel & $-26 \%$ & $-31 \%$ & $-6 \%$ & $-45 \%$ & $-26 \%$ & $-33 \%$ & $-9 \%$ \\
TOTAL FEATURES & $1 \%$ & $-28 \%$ & $-28 \%$ & $-45 \%$ & $-46 \%$ & $-29 \%$ & $-30 \%$
\end{tabular}




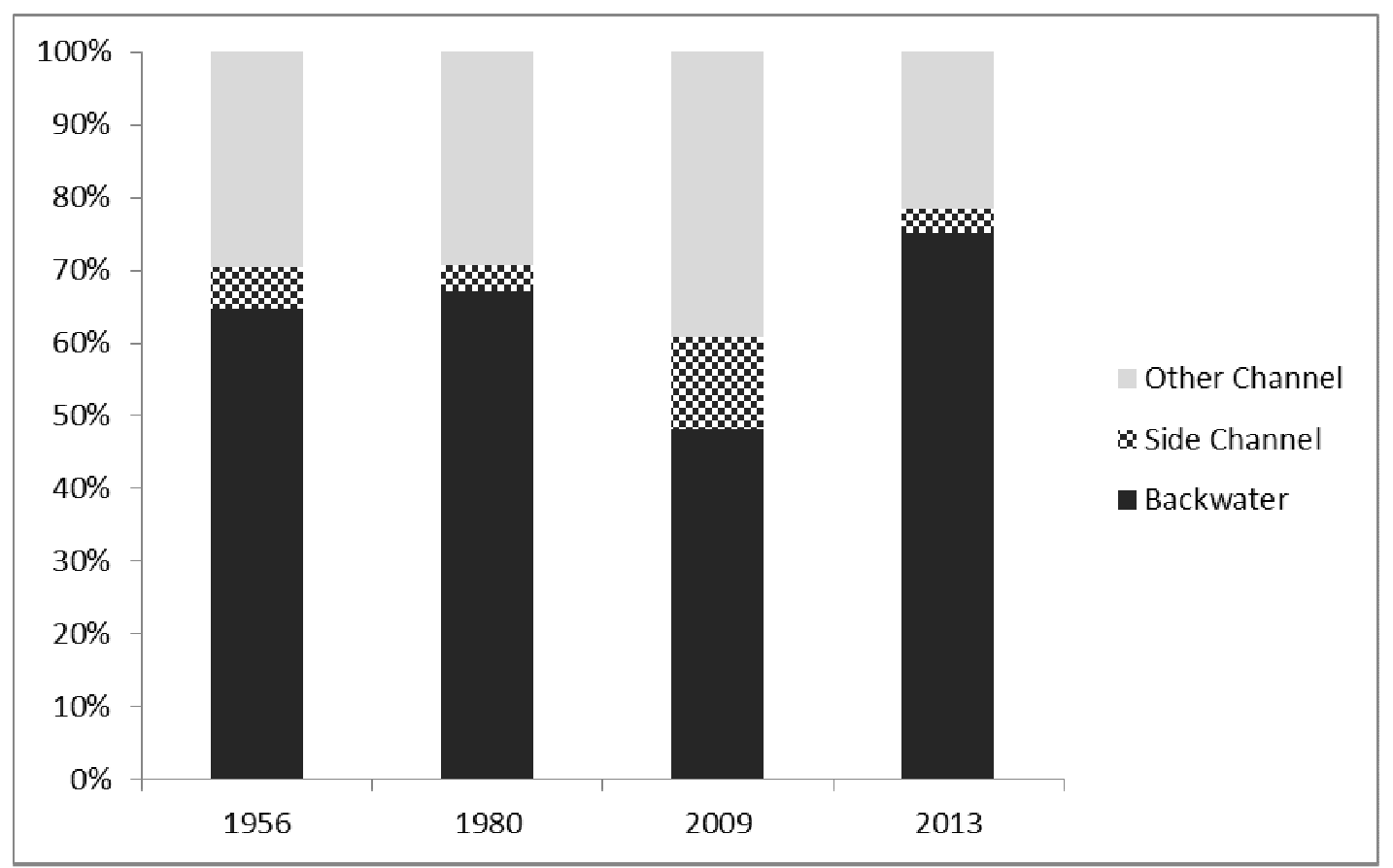

Figure 8. Changes in the proportion of off-channel habitat features mapped from Fort Peck dam downstream approximately $165 \mathrm{~km}$ between 1956 and 2013.

\subsubsection{Habitat trends: 1956, 2009, 2013 Fort Peck dam to North Dakota state line}

The total number of mapped features increased between 1956 and 2009, then declined in 2013 (Table 3). For all habitat types, the number of mapped features was less in 2013 than in 1956 (Table 4). Overall, the total number of mapped features declined by $16 \%$. Side channels and other channels saw the greatest loss of habitat, with a $28 \%$ and $35 \%$ decline, respectively, from 1956 to 2013. Backwaters saw the least decline over time.

Mean length, perimeter, and area for every habitat feature were lowest in 2009, and the 2009 values were significantly lower than 1956 values (Figures 9-11). In general, 2013 values were similar to 2009 values. Means in 2013 were significantly higher than 2009 means for backwaters and side channels, but these means were still significantly lower than 1956 means (Figures 9-11, Appendix 2).

We observed a shift in the relative and absolute number of mapped habitat features between 1956 and 2013. The proportion of mapped habitats appears to be shifting towards more backwaters and fewer side channels and other channels (Figure 12). Backwaters increased from $66.1 \%$ of mapped features in 1956 to $73.3 \%$ of mapped off-channel features in 2013. 
Table 3. The number, length, area, and perimeter of off-channel aquatic habitats mapped from Fort Peck dam downstream to the North Dakota state line using 1956, 2009, and 2013 aerial imagery.

\begin{tabular}{clcccccc}
$\begin{array}{c}\text { Imagery } \\
\text { Date }\end{array}$ & Feature Type & $\begin{array}{c}\text { Total } \\
\text { Number }\end{array}$ & $\begin{array}{c}\text { Total Length } \\
(\mathbf{m})\end{array}$ & $\begin{array}{c}\text { Mean Length } \\
(\mathbf{m})\end{array}$ & $\begin{array}{c}\text { Total Area } \\
(\text { ha) }\end{array}$ & $\begin{array}{c}\text { Mean Area } \\
(\text { ha) }\end{array}$ & $\begin{array}{c}\text { Total Perimeter } \\
(\mathbf{m})\end{array}$ \\
\hline 1956 & Backwater & 347 & $69,156.64$ & $199.30(11.68)$ & 166.28 & $0.48(0.05)$ & $160,736.74$ \\
Perimeter $(\mathbf{m})$
\end{tabular}

For means, standard errors are reported in parentheses. 


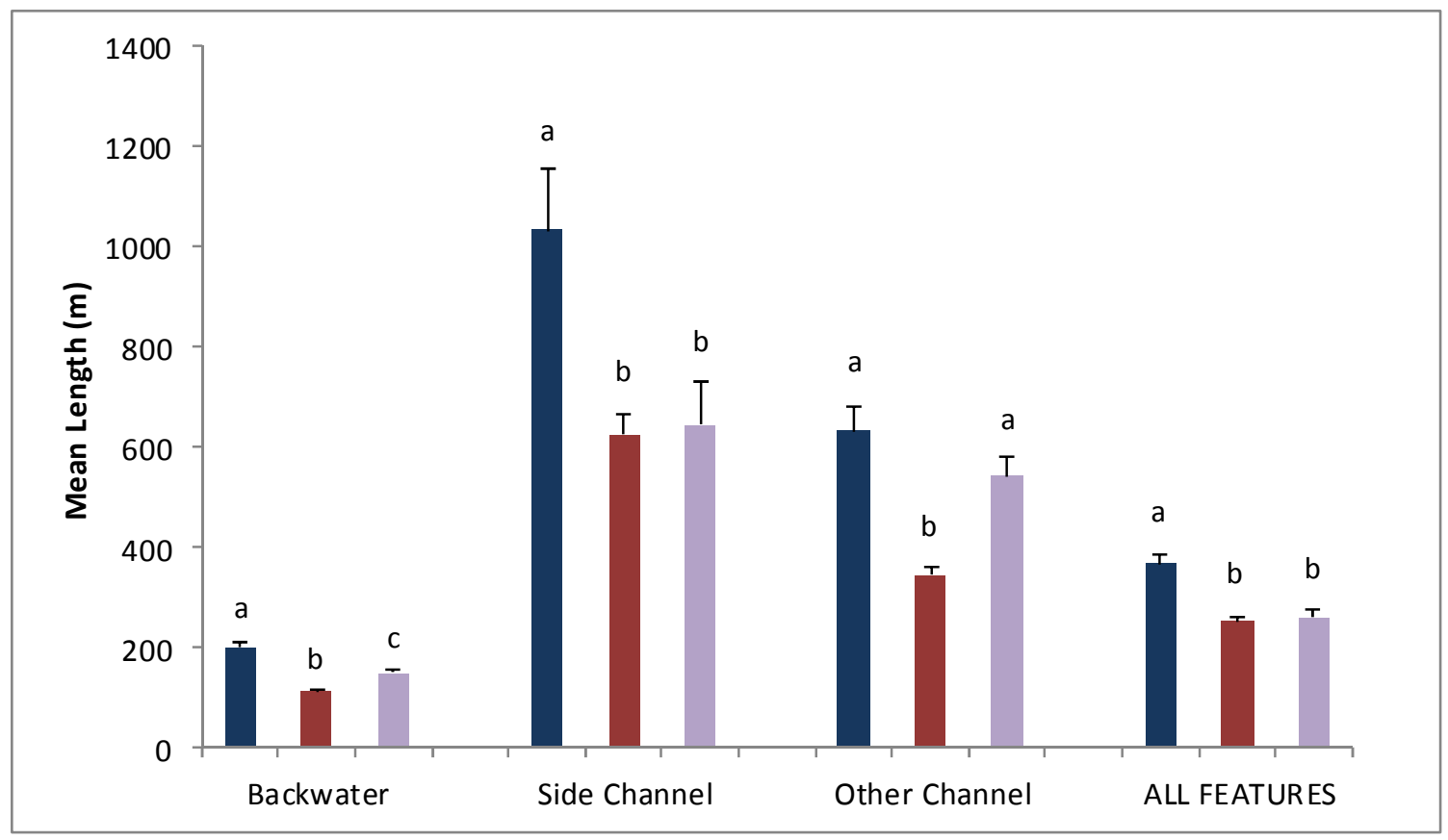

Figure 9. Mean length of off-channel habitat features mapped on the Missouri River between Fort Peck dam and the North Dakota state line. Numbers are presented in chronological order from left to right: dark blue bars are 1956, red bars are 2009, and purple bars are 2013. Letters designate significant differences between years.

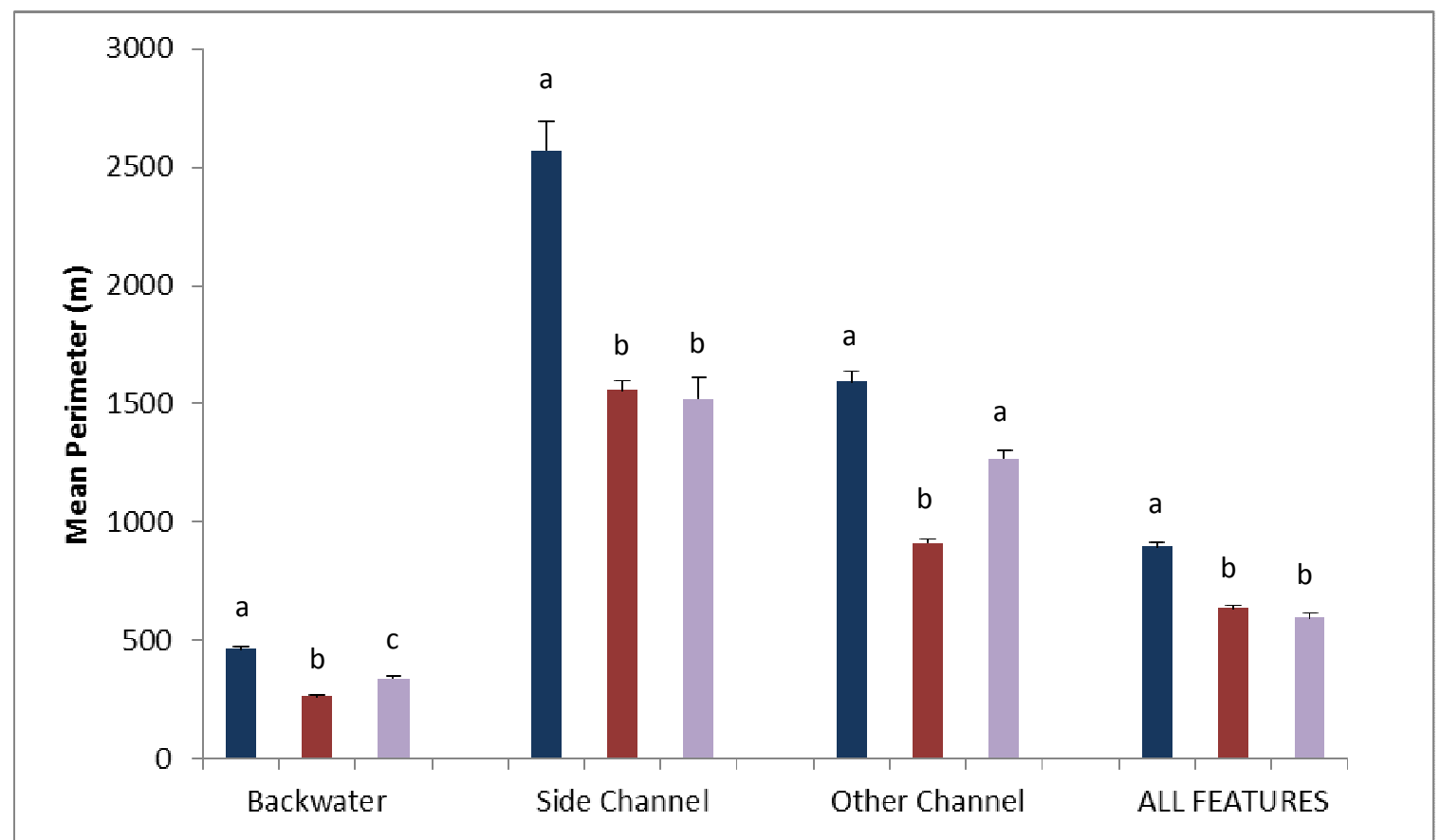

Figure 10. Mean perimeter of off-channel habitat features mapped on the Missouri River between Fort Peck dam and the North Dakota state line. Numbers are presented in chronological order from left to right: dark blue bars are 1956, red bars are 2009, and purple bars are 2013. Letters designate significant differences between years. 


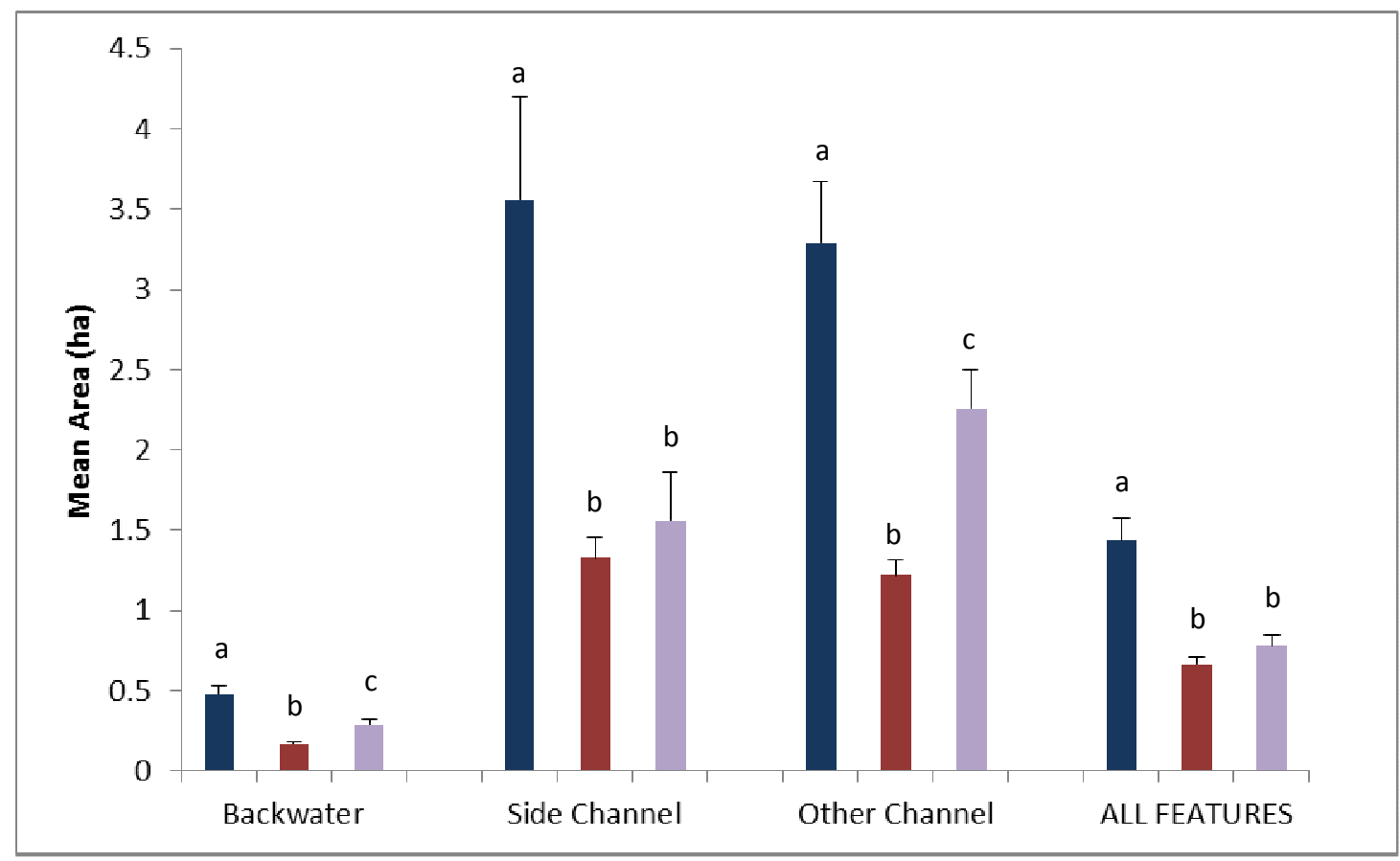

Figure 11. Mean area of off-channel habitat features mapped on the Missouri River between Fort Peck dam and the North Dakota state line. Numbers are presented in chronological order from left to right: dark blue bars are 1956, red bars are 2009, and purple bars are 2013. Letters designate significant differences between years.

Table 4. Relative changes in the number, length, area, and perimeter of habitat features between 1956 and 2013 from Fort Peck dam to the North Dakota state line.

\begin{tabular}{l|ccccccc} 
& $\begin{array}{c}\text { Number } \\
\text { of } \\
\text { Features }\end{array}$ & $\begin{array}{c}\text { Total } \\
\text { Length }\end{array}$ & $\begin{array}{c}\text { Mean } \\
\text { Length }\end{array}$ & $\begin{array}{c}\text { Total } \\
\text { Area }\end{array}$ & $\begin{array}{c}\text { Mean } \\
\text { Area }\end{array}$ & $\begin{array}{c}\text { Total } \\
\text { Perimeter }\end{array}$ & $\begin{array}{c}\text { Mean } \\
\text { Perimeter }\end{array}$ \\
\hline Backwater & $-7 \%$ & $-30 \%$ & $-25 \%$ & $-43 \%$ & $-40 \%$ & $-32 \%$ & $-27 \%$ \\
Side Channel & $-28 \%$ & $-55 \%$ & $-38 \%$ & $-68 \%$ & $-56 \%$ & $-57 \%$ & $-20 \%$ \\
Other Channel & $-35 \%$ & $-80 \%$ & $-14 \%$ & $-56 \%$ & $-31 \%$ & $-48 \%$ & $-41 \%$ \\
TOTAL FEATURES & $-16 \%$ & $-41 \%$ & $-29 \%$ & $-54 \%$ & $-46 \%$ & $-44 \%$ & $-33 \%$
\end{tabular}




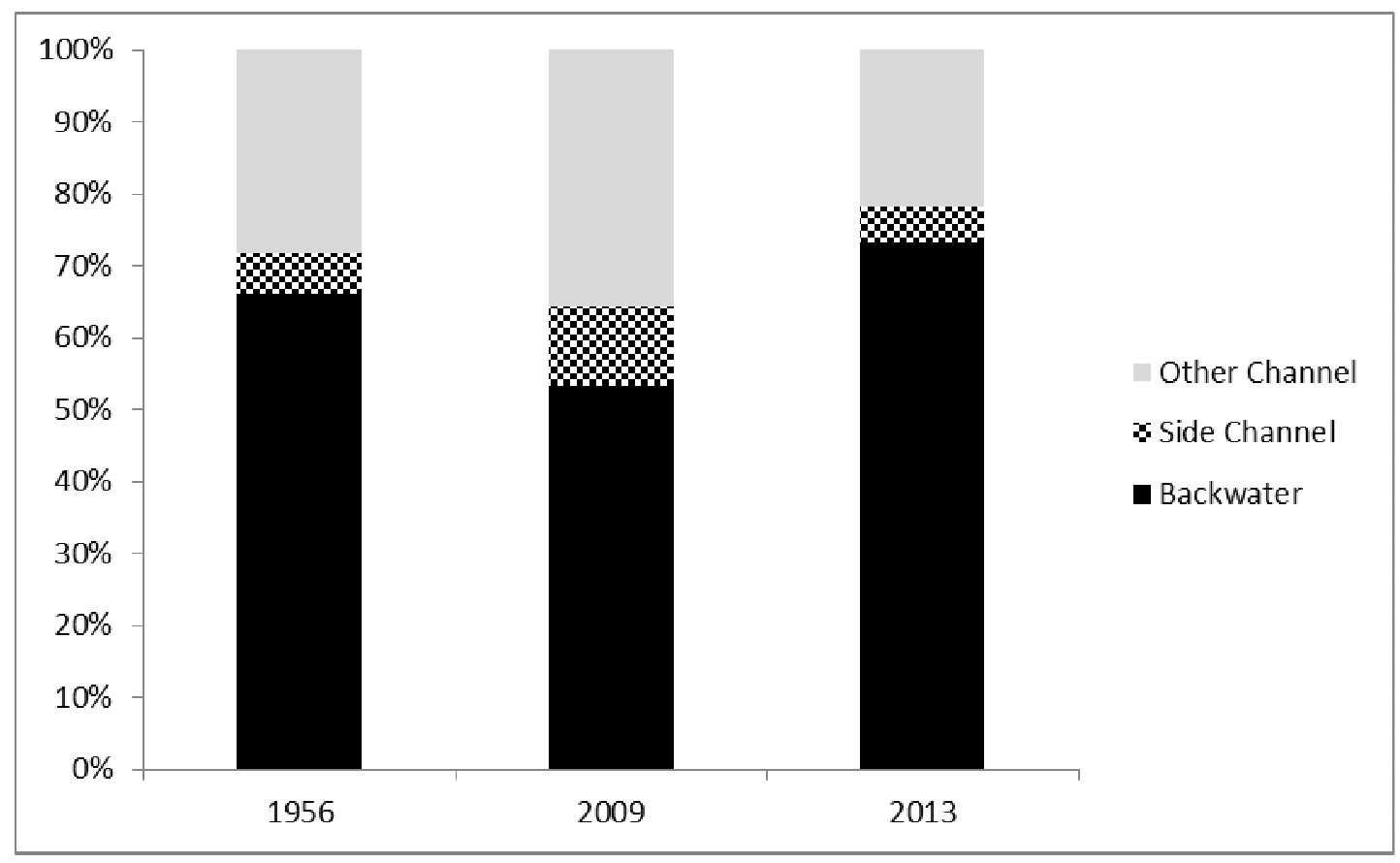

Figure 12. Changes in proportion of off-channel habitat features mapped between Fort Peck dam and the North Dakota state line between 1956 and 2013.

\subsection{DISCUSSION}

Although the impacts of an impoundment on a large river may be mitigated somewhat with increasing distance downstream from the dam (Stanford et al 1996), we have demonstrated that there has been significant loss of off-channel habitat on the Missouri River below Fort Peck dam to the North Dakota state line between 1956 and 2013. Because we documented loss of habitat for the entire dataset, and the trends were similar between both the entire dataset and the subset of data including the 1980 imagery, the discussion will focus on the entire dataset only.

Perhaps the single largest change in the Missouri River system has been the loss of sediment. Between 1937-1953, during which time 3 major dams on the Missouri River were completed: Fort Peck dam; Fort Randall dam in South Dakota; and Garrison dam, located in North Dakota $500 \mathrm{~km}$ downstream of Fort Peck dam; turbidity decreased by more than $50 \%$ at water samples collected at the Kansas City, Kansas, water-treatment plant as a result of sediment retention behind the dams (Blevins 2006). Sediment is a critical component of maintaining the balance of scouring and deposition in natural river systems. Impoundments on the river have not only removed sediment from the water, but they have also reduced peak run-off flows relative to their historic values. Instead of flood-induced scouring resulting in sediment deposition, sedimentstarved waters continue to degrade the channel (National Research Council 2011). Tributaries to regulated rivers are a source of sediment. For this reach of the Missouri River, the Milk River is the largest tributary between Fort Peck dam and the Yellowstone River. Although the Milk River is sediment-laden (Figure 13), the volume of sediment it contributes to the Missouri River is just a fraction of the sediment being retained by Fort Peck reservoir. 


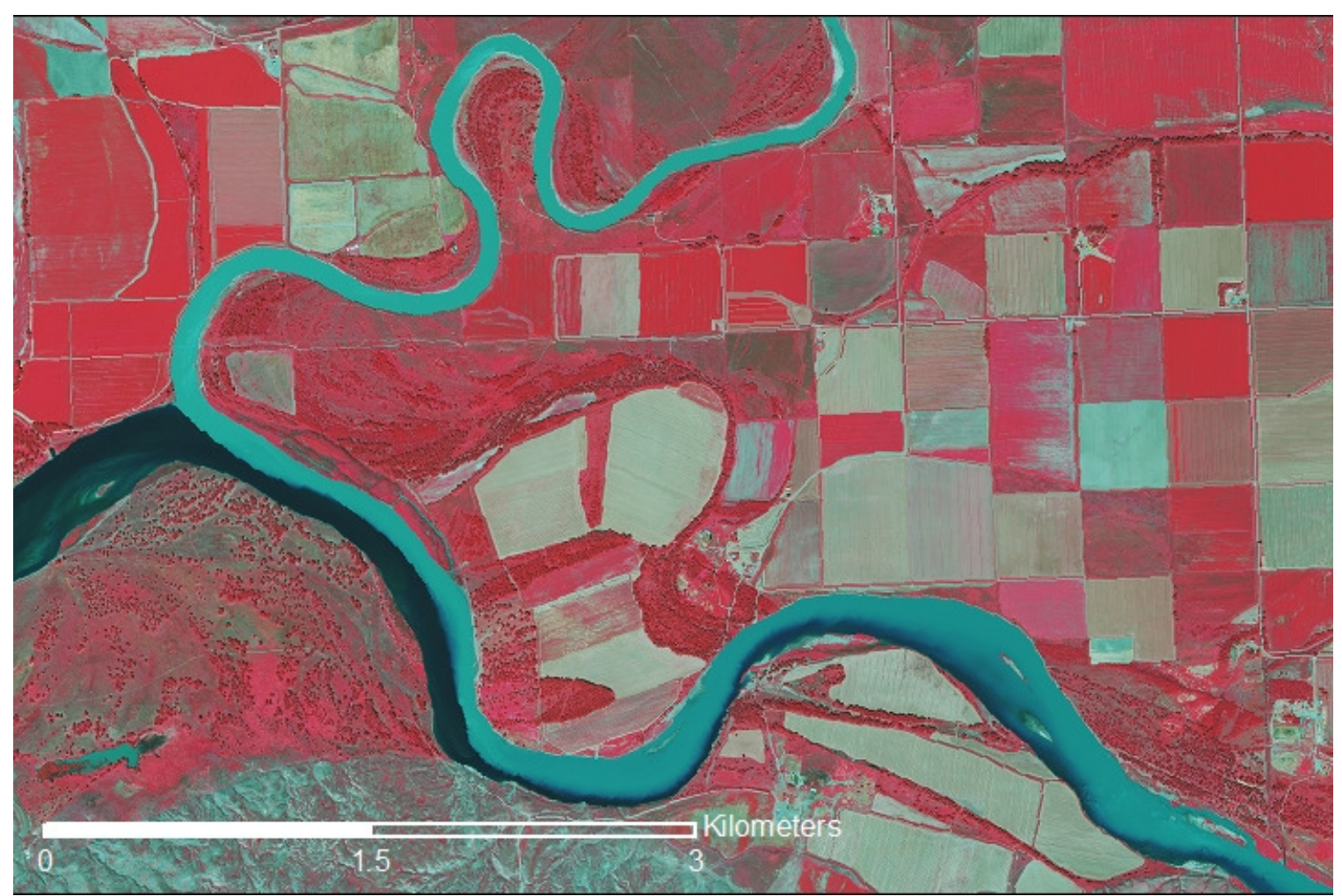

Figure 13. The Milk River, entering the Missouri River from the north, is the largest, most sediment-rich tributary on the Missouri River between Fort Peck dam and the Yellowstone River.

Previously, we documented an increase in the number of each habitat type between 1956 and 2009 , as well as an increase in the total length and total perimeter of side channels, other channels, and all features combined (Owen and Hahn 2014). One possible explanation for this increase may be due to sediment deposition in the main channel of the Missouri River during the mid-2000s drought, when discharge was very low. This aggradation of the river bed would have resulted in higher surface water levels, and more connectivity between the main channel and offchannel habitats like backwaters and side channels (Tyler Haddix, personal communication). We hypothesized in the previous study that the 2011 flood may have served to reorganize the river below Fort Peck dam and act to "reset" the river by inundating floodplains, depositing sediments, and scouring new off-channel habitat features. However, it appears the defining factor during the flood event was sediment scouring in the main channel, which led to bed degradation and lowering of surface water levels. Since the Missouri River below Fort Peck dam has less sediment than historically, there is not enough sediment in the water to deposit in the stream channel and on the floodplain when floodwaters recede, leading to a net loss of sediment during large scouring events. This cut off some off-channel habitats from the main river completely (Figure 14) and converted some side channels to backwater habitats (Owen and Hahn 2014). This may help explain why there was a significant increase in mean area of backwaters between 2009 and 2013. Despite this increase, off-channel habitats have experienced a net loss over time. In this study we documented a significant decline in side channel habitats since the completion of Fort Peck dam. Phelps et al (2010) documented that age-0 shovelnose and pallid sturgeon seek specific microhabitats in the Middle Mississippi River, including areas near islands within side channels. Our results suggest this section of the Missouri River is losing potentially important habitat for young pallid sturgeon. 


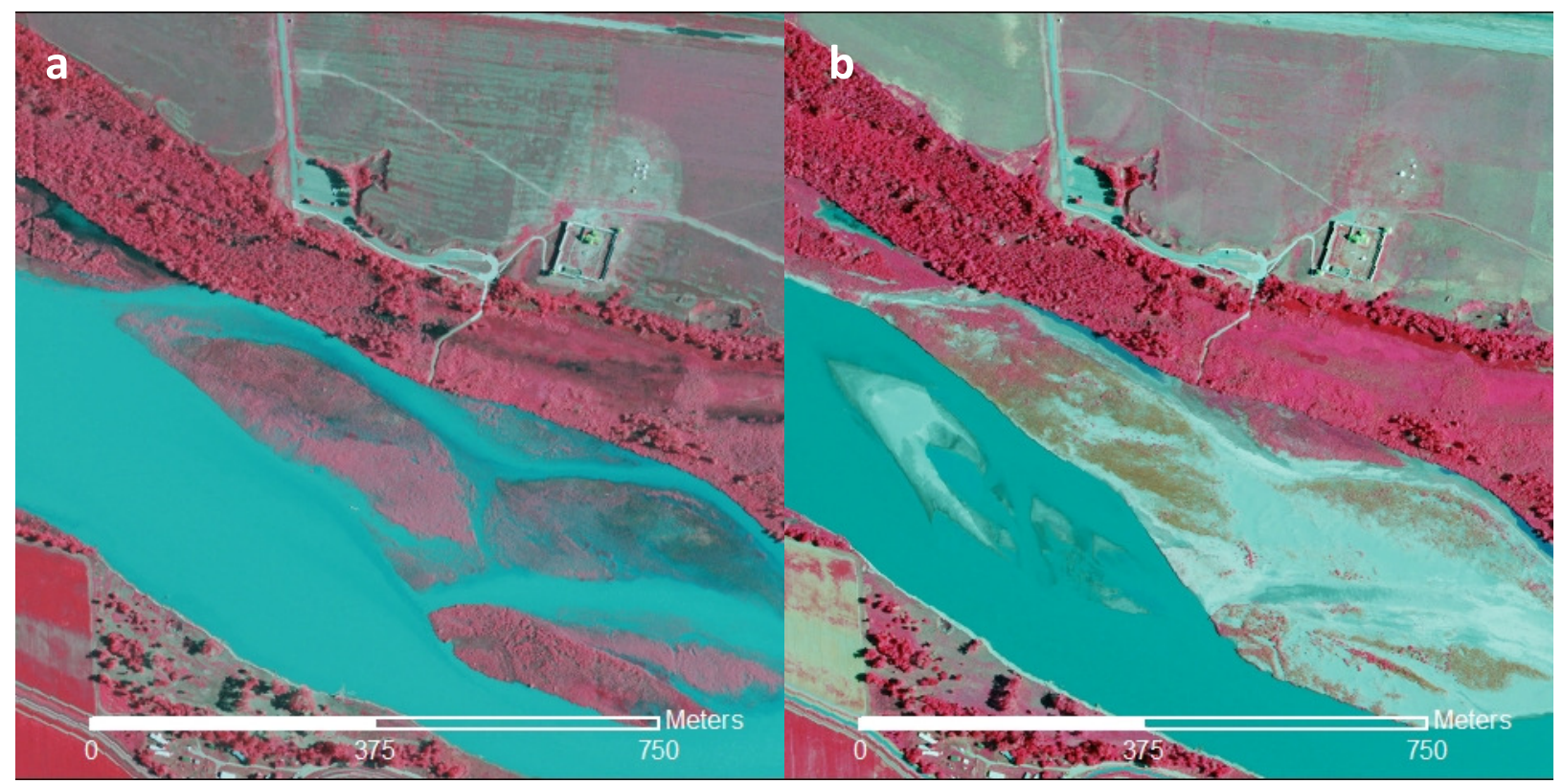

Figure 14. Scouring of the main river channel during the 2011 flood caused the river bed to degrade, and a 2009 side channel (a) was cut off from the main channel in 2013 (b).

Natural recruitment of pallid sturgeon has not been documented in the upper Missouri River in several decades (Webb et al 2005, Braaten et al 2008), and fewer than 100 wild pallid sturgeon individuals are estimated to remain in this part of the Missouri River (Dave Fuller, personal communication). Prior to regulation, pallid sturgeon used all features of the Missouri River and its floodplain, including backwaters, sloughs, and main channel pools and snags for spawning and larval rearing, and the loss of these features has likely eliminated pallid sturgeon reproduction in much of the Missouri River (National Research Council 2011). Beginning in the 1990s shortly after the pallid sturgeon was listed as endangered, a pallid sturgeon propagation and reintroduction program was initiated to prevent the extirpation of the species (Webb et al 2005, Braaten et al 2012). If natural spawning does occur, many larval young are suspected to drift downstream after hatching, settling out in Lake Sakakawea, where habitat conditions are unsuitable and few, if any, larvae survive (Webb et al 2005). Pallid sturgeon larvae may drift an average of 245-530 km from where they hatch before settling out of the main current and seeking off-channel habitat (Braaten et al 2008). Below Fort Peck dam, only $340 \mathrm{~km}$ of free-flowing habitat exist before transitioning to lentic conditions at the headwaters of Lake Sakakawea. Depending on where spawning occurs, there may not be enough lotic habitat available for larval drift before settlement into benthic habitat. This may explain the lack of larval survival and recruitment of pallid sturgeon in the Upper Missouri River system (Braaten et al 2008).

Although suitable habitat may be insufficient to support natural reproduction of wild sturgeon in this section of the Missouri River, Shuman et al. (2011) and Braaten et al (2012) documented that conditions are suitable for growth and development of young pallid sturgeon, though Braaten et al. noted that current growth rates may be lower than historical growth rates. This may be due in part to suppressed water temperatures from hypolimnetic releases from Fort Peck dam that keep water temperatures suppressed longer into the spring and summer over historic 
ranges (Shuman 2011, Braaten et al 2012). Kappenman et al (2013) estimated the optimal temperature for pallid sturgeon embryo incubation is $17-18^{\circ} \mathrm{C}$. The thermal regime of the Missouri River below Fort Peck dam rarely reaches optimal temperature conditions, potentially inhibiting or delaying spawning and impeding embryo incubation (Kappenman et al 2013).

The results of this study have important implications for fisheries managers in the Upper Missouri River Basin. Habitat loss is occurring below Fort Peck dam for all off-channel habitat types. Outside of removing impoundments on the Missouri River, the next best option is habitat restoration. Because Fort Peck dam has such a large influence on the hydrology of the Missouri River, it will not be possible to restore the Upper Missouri River ecosystem to pristine conditions. Ideally, restoration targets will be process-oriented to increase self-sustainability of the ecosystem (Amoros 2001). Increasing flows to increase hydrologic connectivity and enhancing temperature suitability for spawning pallid sturgeon are hydrologic alterations that may help restore habitat (Stanford et al 1996) and are feasible actions for this system. Proposed modifications for the operation of Fort Peck dam to meet these hydrologic goals may enhance pallid sturgeon spawning and recruitment (Braaten et al 2012). However, Jacobson et al. (2004) noted that hydrologic alterations alone may not be sufficient to create more suitable aquatic habitat on intensively altered rivers. If this is the case in the Upper Missouri Basin, more drastic measures, like the Corps of Engineers Shallow Water Habitat program, may be initiated to create or restore off-channel habitat (National Research Council 2011). Under this program, side channels and backwaters are created, enhanced, or reconnected to the main river channel by excavating sediments, which are then deposited either directly in the main channel or on the bank where they may eventually enter the water column during a flood event. Any construction of side channels or other off-channel habitats should be designed to be dynamic features that will change over time either by filling in with sediment or capturing the main channel (Jacobson et al 2004). This sort of enhancement project would depend on the willingness of landowners to participate in the program, since there is little public land along this stretch of the Missouri River. The addition of sediment back to waters below Fort Peck dam, along with the proposed hydrologic modifications to the operation of Fort Peck dam, are potential avenues to explore for habitat restoration. 


\section{LITERATURE CITED}

Amoros, C. 2001. The concept of habitat diversity between and within ecosystems applied to river side-arm restoration. Environmental Management 28(6): 805-817.

Bayley, P.B. 1995. Understanding large river-floodplain ecosystems. Bioscience 45(3): 153158.

Blevins, D.W. 2006. The response of suspended sediment, turbidity, and discharge to historical alterations of the Missouri River. U.S. Geological Survey Circular 1301. 8pp.

Braaten, P.J., D.B. Fuller, L.D. Holte, R.D. Lott, W. Viste, T.F. Brandt, and R.G. Legare. 2008. Drift dynamics of larval pallid sturgeon in a natural side channel of the Upper Missouri River, Montana. North American Journal of Fisheries Management 28: 808-826.

Braaten, P.J., D.B. Fuller, R.D. Lott, T.M. Haddix, L.D. Holte, R.H. Wilson, M.L. Bartron, J.A. Kalie, P.W. DeHaan, W.R. Ardren, R.J. Holm, and M.E. Jaeger. 2012. Natural growth and diet of known-age pallid sturgeon (Scaphirhynchus albus) early life stages in the upper Missouri River Basin, Montana and North Dakota. Journal of Applied Ichthyology 28: 496-504.

Dryer, M.P. and A.J. Sandvol. 1993. Pallid sturgeon recovery plan. U.S. Fish and Wildlife Service, Bismarck, North Dakota. 55pp.

Jacobson, R.B., H.E. Johnson, M.S. Laustrup, G.J. D’Urso, and J.M. Reuter. 2004. Physical habitat dynamics in four side-channel chutes, Lower Missouri River. U.S. Geological Survey OFR 2004-1071, Reston, Virginia. 66pp.

Kappenman, K.M., M.A.H. Webb, and M. Greenwood. 2013. The effect of temperature on embryo survival and development in pallid sturgeon Scaphirhynchus albus (Forbes \& Richardson 1905) and shovelnose sturgeon S. platorynchus (Rafinesque 1820). Journal of Applied Ichthyology 29: 1193-1203.

Lehtinen, R.M., N.D. Mundahl, and J.C. Madejczyk. 1997. Autumn use of woody snags by fishes in backwater and channel border habitats of a large river. Environmental Biology of Fishes 49: 7-19.

Ligon, F.K., W.E. Dietrich, and W.J. Trush. 1995. Downstream ecological effects of dams. Bioscience 45(3): 183-192.

National Research Council. 2011. Missouri River Planning: Recognizing and Incorporating Sediment Management. The National Academies Press, Washington, DC. 164 pp. 
Owen, S. and J. Hahn. 2014. Trends in of-channel fish habitat on the Missouri River below Fort Peck Dam: 1956-2013. Report to Montana Fish, Wildlife, and Parks. Montana Natural Heritage Program, Helena, Montana. 22 pp. Available online at https://archive.org/details/3253C0967CE54F979A8C2B11AE6BEA6B.

Phelps, Q.E. S.J. Tripp, J.E. Garvey, D.P. Herzog, D.E. Ostendorf, J.W. Ridings, J.W. Crites, and R.A Hrabik. 2010. Habitat use during early life history infers recovery needs for shovelnose sturgeon and pallid sturgeon in the Middle Mississippi River. Transactions of the American Fisheries Society 139: 1060-1068.

Sedell, J.R., G.H. Reeves, F.R. Hauer, J.A. Stanford, and C.P. Hawkins. 1990. Role of refugia in recovery from disturbances: modern fragmented and disconnected river systems. Environmental Management 14(5): 711-724.

Sheaffer, W.A. and J.G. Nickum. 1986. Backwater areas as nursery habitats for fishes in Pool 13 of the Upper Mississippi River. Hydrobiologia 136: 131-140.

Shields, F.D. Jr., A. Simon, and L.J. Steffen. 2000. Reservoir effects on downstream river channel migration. Environmental Conservation 27(1): 54-66.

Shuman, D.A., R.A. Klumb, R.H. Wilson, M.E. Jaeger, T. Haddix, W.M. Gardner, W.J. Doyle, P.T. Horner, M. Ruggles, K.D. Steffensen, S. Stukel, and G.A. Wanner. 2011. Pallid sturgeon size structure, condition, and growth in the Missouri River Basin. Journal of Applied Ichthyology 27: 269-281.

Stanford, J.A., J.V. Ward, W.J. Liss, C.A. Frissell, R.N. Williams, J.A. Lichatowich, and C.C. Coutant. 1996. A general protocol for restoration of regulated rivers. Regulated Rivers: Research \& Management 12: 391-413.

Ward, J.V. and J.A. Stanford. 1995. Ecological connectivity in alluvial river ecosystems and its disruption by flow regulation. Regulated Rivers: Research and Management 11: 105119.

Webb, M.A.H., J.E. Williams, and L.R. Hildebrand. 2005. Recovery program review for endangered pallid sturgeon in the Upper Missouri River Basin. Reviews in Fisheries Science 13: 165-176.

Whitley, J.R. and R.S. Campbell. 1974. Some aspects of water quality and biology of the Missouri River. Transactions, Missouri Academy of Science 7/8: 60-72.

Yager, L.A., M.D. Dixon, T.C. Cowman, and D.A. Soluk. 2013. Historic changes (1941-2008) in side channel and backwater habitats on an unchannelized reach of the Missouri River. River Research and Applications 29(4): 493-501. 


\section{Appendix 1}

ANOVA Tables for 1956, 1980, 2009, 2013 Data Subset 
Table A. ANOVA results for length of each off-channel habitat feature.

\begin{tabular}{|c|c|c|c|c|c|c|}
\hline Source of Variation & SS & $d f$ & MS & $F$ & $P$-value & F crit \\
\hline Between Groups & 664560.8 & 3 & 221520.3 & 8.1929 & 0.00002 & 2.6165 \\
\hline Within Groups & 20738307 & 767 & 27038.21 & & & \\
\hline Total & 21402868 & 770 & & & & \\
\hline \multicolumn{7}{|c|}{ Tukey Post Hoc Comparison } \\
\hline Comparison & $q$ & $q, 0.05, \infty, 4$ & $p$ & Conclusion & & \\
\hline 1956 vs 2009 & 6.948 & 3.633 & $\mathrm{p}<0.001$ & $1956 \neq 2009$ & & \\
\hline 1956 vs 2013 & 3.821 & 3.633 & $p<0.05$ & $1956 \neq 2013$ & & \\
\hline 1956 vs 1980 & 3.393 & 3.633 & $p>0.05$ & $1956=1980$ & & \\
\hline 1980 vs 2009 & 3.988 & 3.633 & $p<0.05$ & $1980 \neq 2009$ & & \\
\hline 1980 vs 2013 & 0.656 & 3.633 & $p>0.05$ & $1980=2013$ & & \\
\hline 2013 vs 2009 & 3.102 & 3.633 & $p>0.05$ & $2013=2009$ & & \\
\hline \multicolumn{7}{|l|}{ ANOVA--Side Channel } \\
\hline Source of Variation & SS & $d f$ & MS & $F$ & P-value & F crit \\
\hline Between Groups & 1692833 & 3 & 564277.6 & 3.5318 & 0.0181 & 2.7094 \\
\hline Within Groups & 13900002 & 87 & 159770.1 & & & \\
\hline Total & 15592835 & 90 & & & & \\
\hline \multicolumn{7}{|c|}{ Tukey Post Hoc Comparison } \\
\hline Comparison & $q$ & $q, 0.05, \infty, 4$ & $p$ & Conclusion & & \\
\hline 1980 vs 2013 & 2.593 & 3.737 & $p>0.05$ & $1980=2013$ & & \\
\hline 1980 vs 2009 & Do not test & & & & & \\
\hline 1980 vs 1956 & Do not test & & & & & \\
\hline 1956 vs 2013 & Do not test & & & & & \\
\hline 1956 vs 2009 & Do not test & & & & & \\
\hline 2009 vs 2013 & Do not test & & & & & \\
\hline \multicolumn{7}{|l|}{ ANOVA--Other Channel } \\
\hline Source of Variation & SS & $d f$ & MS & $F$ & P-value & F crit \\
\hline Between Groups & 6050485 & 3 & 2016828 & 13.0207 & 4.03E-08 & 2.6278 \\
\hline Within Groups & 60408803 & 390 & 154894 & & & \\
\hline Total & 66459288 & 393 & & & & \\
\hline \multicolumn{7}{|c|}{ Tukey Post Hoc Comparison } \\
\hline Comparison & $q$ & $q 0.05, v, 4$ & $p$ & Conclusion & & \\
\hline 1956 vs 2009 & 6.861 & 3.737 & $\mathrm{p}<0.001$ & $1956 \neq 2009$ & & \\
\hline 1956 vs 2013 & 0.730 & 3.737 & $p>0.05$ & $1956=2013$ & & \\
\hline 1956 vs 1980 & Do not test & & & & & \\
\hline 1980 vs 2009 & 6.824 & 3.737 & $p<0.001$ & $1980 \neq 2009$ & & \\
\hline 1980 vs 2013 & 0.118 & 3.737 & $p>0.05$ & $1980=2013$ & & \\
\hline 2013 vs 2009 & 5.281 & 3.737 & $p<0.05$ & $2013 \neq 2009$ & & \\
\hline \multicolumn{7}{|l|}{ ANOVA--All Features } \\
\hline Source of Variation & SS & $d f$ & MS & $F$ & P-value & F crit \\
\hline Between Groups & 1861532 & 3 & 620511 & 5.346 & 0.0012 & 2.612 \\
\hline Within Groups & 145325522 & 1252 & 116075 & & & \\
\hline Total & 147187054 & 1255 & & & & \\
\hline \multicolumn{7}{|c|}{ Tukey Post Hoc Comparison } \\
\hline Comparison & $q$ & $q, 0.05, \infty, 3$ & $p$ & Conclusion & & \\
\hline 1956 vs 2013 & 4.747 & 3.633 & $\mathrm{p}<0.025$ & $1956 \neq 2013$ & & \\
\hline 1956 vs 2009 & 4.977 & 3.663 & $p<0.05$ & $1956 \neq 2009$ & & \\
\hline 1956 vs 1980 & 2.562 & 3.663 & $p>0.05$ & $1956=1980$ & & \\
\hline 1980 vs 2013 & 5.582 & 3.633 & $p>0.05$ & $1980=2013$ & & \\
\hline 1980 vs 2009 & Do not test & & & & & \\
\hline 2009 vs 2013 & 0.452 & 3.633 & $p>0.05$ & $2009=2013$ & & \\
\hline
\end{tabular}


Table B. ANOVA results for perimeter of each off-channel habitat feature.

\begin{tabular}{|c|c|c|c|c|c|c|}
\hline \multicolumn{7}{|l|}{ ANOVA--Backwater } \\
\hline Source of Variation & SS & $d f$ & MS & $F$ & P-value & F crit \\
\hline Between Groups & 3085935 & 3 & 1028645 & 6.4714 & 0.00025 & 2.6165 \\
\hline Within Groups & 121917193 & 767 & 158953 & & & \\
\hline Total & 125003128 & 770 & & & & \\
\hline \multicolumn{7}{|c|}{ Tukey Post Hoc Comparison } \\
\hline Comparison & $q$ & $q, 0.05, \infty, 4$ & $p$ & Conclusion & & \\
\hline 1956 vs 2009 & 6.106 & 3.633 & $p<0.001$ & $1956 \neq 2009$ & & \\
\hline 1956 vs 2013 & 3.528 & 3.633 & $p<0.05$ & $1956=2013$ & & \\
\hline 1956 vs 1980 & Do not test & & & & & \\
\hline 1980 vs 2009 & 3.794 & 3.633 & $p<0.05$ & $1980 \neq 2009$ & & \\
\hline 1980 vs 2013 & 1.039 & 3.633 & $p>0.5$ & $1980=2013$ & & \\
\hline 2013 vs 2009 & 2.539 & 3.633 & $p>0.05$ & $2013=2009$ & & \\
\hline \multicolumn{7}{|l|}{ ANOVA--Side Channel } \\
\hline Source of Variation & SS & $d f$ & MS & $F$ & $P$-value & F crit \\
\hline Between Groups & 11765260 & 3 & 3921753 & 3.3481 & 0.0227 & 2.7094 \\
\hline Within Groups & 101906480 & 87 & 1171339 & & & \\
\hline Total & 113671739 & 90 & & & & \\
\hline \multicolumn{7}{|c|}{ Tukey Post Hoc Comparison } \\
\hline Comparison & $q$ & $q, 0.05, \infty, 4$ & $p$ & Conclusion & & \\
\hline 1980 vs 2013 & 2.645 & 3.737 & $p>0.05$ & $1980=2013$ & & \\
\hline 1980 vs 2009 & Do not test & & & & & \\
\hline 1980 vs 1956 & Do not test & & & & & \\
\hline 1956 vs 2013 & Do not test & & & & & \\
\hline 1956 vs 2009 & Do not test & & & & & \\
\hline 2009 vs 2013 & Do not test & & & & & \\
\hline \multicolumn{7}{|l|}{ ANOVA--Other Channel } \\
\hline Source of Variation & SS & $d f$ & MS & $F$ & P-value & F crit \\
\hline Between Groups & 31414455 & 3 & 10471485 & 9.5495 & 4.24E-06 & 2.6278 \\
\hline Within Groups & 427652057 & 390 & 1096544 & & & \\
\hline Total & 459066512 & 393 & & & & \\
\hline \multicolumn{7}{|c|}{ Tukey Post Hoc Comparison } \\
\hline Comparison & $q$ & $q 0.05, v, 4$ & $p$ & Conclusion & & \\
\hline 1980 vs 2009 & 6.409 & 3.737 & $p<0.001$ & $1980 \neq 2009$ & & \\
\hline 1980 vs 2013 & 1.147 & 3.737 & $p>0.5$ & $1980=2013$ & & \\
\hline 1980 vs 1956 & Do not test & & & & & \\
\hline 1956 vs 2009 & 5.594 & 3.737 & $p<0.001$ & $1956 \neq 2009$ & & \\
\hline 1956 vs 2013 & 1.001 & 3.737 & $p>0.5$ & $1956=2013$ & & \\
\hline 2013 vs 2009 & 3.834 & 3.737 & $p<0.05$ & $2013 \neq 2009$ & & \\
\hline \multicolumn{7}{|l|}{ ANOVA--All Features } \\
\hline Source of Variation & SS & $d f$ & MS & $F$ & $P$-value & F crit \\
\hline Between Groups & 10277992 & 3 & 3425997 & 4.3608 & 0.0046 & 2.612 \\
\hline Within Groups & 983626099 & 1252 & 785644 & & & \\
\hline Total & 993904091 & 1255 & & & & \\
\hline \multicolumn{7}{|c|}{ Tukey Post Hoc Comparison } \\
\hline Comparison & $q$ & $q, 0.05, \infty, 3$ & $p$ & Conclusion & & \\
\hline 1956 vs 2013 & 4.622 & 3.633 & $p<0.025$ & $1956 \neq 2013$ & & \\
\hline 1956 vs 2009 & 3.732 & 3.663 & $p<0.05$ & $1956 \neq 2009$ & & \\
\hline 1956 vs 1980 & 1.696 & 3.663 & $p>0.5$ & $1956=1980$ & & \\
\hline 2009 vs 2013 & 3.316 & 3.633 & $p>0.05$ & $2009=2013$ & & \\
\hline 2009 vs 1980 & Do not test & & & & & \\
\hline 1980 vs 2013 & 1.56 & 3.633 & $p>0.5$ & $1980=2013$ & & \\
\hline
\end{tabular}


Table C. ANOVA results for area of each off-channel habitat feature.

\begin{tabular}{|c|c|c|c|c|c|c|}
\hline Source of Variation & SS & $d f$ & MS & $F$ & $P$-value & F crit \\
\hline Between Groups & 9.965 & 3 & 3.32 & 9.434 & 0.000004 & 2.6165 \\
\hline Within Groups & 270.03 & 767 & 0.35 & & & \\
\hline Total & 280 & 770 & & & & \\
\hline \multicolumn{7}{|c|}{ Tukey Post Hoc Comparison } \\
\hline Comparison & $q$ & $q, 0.05, \infty, 4$ & $p$ & Conclusion & & \\
\hline 1956 vs 2009 & 7.491 & 3.633 & $p<0.001$ & $1956 \neq 2009$ & & \\
\hline 1956 vs 2013 & 4.28 & 3.633 & $p<0.01$ & $1956 \neq 2013$ & & \\
\hline 1956 vs 1980 & 3.935 & 3.633 & $p<0.05$ & $1956 \neq 1980$ & & \\
\hline 1980 vs 2009 & 3.992 & 3.633 & $p<0.05$ & $1980 \neq 2009$ & & \\
\hline 1980 vs 2013 & 0.594 & 3.633 & $p>0.5$ & $1980=2013$ & & \\
\hline 2013 vs 2009 & 3.167 & 3.633 & $p>0.1$ & $2013=2009$ & & \\
\hline \multicolumn{7}{|l|}{ ANOVA--Side Channel } \\
\hline Source of Variation & SS & $d f$ & MS & $F$ & $P$-value & F crit \\
\hline Between Groups & 68.2 & 3 & 22.73 & 6.539 & 0.00049 & 2.7094 \\
\hline Within Groups & 302.45 & 87 & 3.48 & & & \\
\hline Total & 370.65 & 90 & & & & \\
\hline \multicolumn{7}{|c|}{ Tukey Post Hoc Comparison } \\
\hline Comparison & $q$ & $q, 0.05, \infty, 4$ & $p$ & Conclusion & & \\
\hline 1980 vs 2013 & 3.526 & 3.737 & $p>0.05$ & $1980=2013$ & & \\
\hline 1980 vs 2009 & Do not test & & & & & \\
\hline 1980 vs 1956 & Do not test & & & & & \\
\hline 1956 vs 2013 & Do not test & & & & & \\
\hline 1956 vs 2009 & Do not test & & & & & \\
\hline 2009 vs 2013 & Do not test & & & & & \\
\hline \multicolumn{7}{|l|}{ ANOVA--Other Channel } \\
\hline Source of Variation & SS & $d f$ & MS & $F$ & P-value & F crit \\
\hline Between Groups & 312.26 & 3 & 104.09 & 10.448 & $1.26 \mathrm{E}-06$ & 2.6278 \\
\hline Within Groups & 3885.3 & 390 & 9.962 & & & \\
\hline Total & 4197.55 & 393 & & & & \\
\hline \multicolumn{7}{|c|}{ Tukey Post Hoc Comparison } \\
\hline Comparison & $q$ & $q 0.05, v, 4$ & $p$ & Conclusion & & \\
\hline 1956 vs 2009 & 6.755 & 3.737 & $p<0.001$ & $1956 \neq 2009$ & & \\
\hline 1956 vs 2013 & 2.224 & 3.737 & $p>0.2$ & $1956=2013$ & & \\
\hline 1956 vs 1980 & Do not test & & & & & \\
\hline 1980 vs 2009 & 5.958 & 3.737 & $p<0.001$ & $1980 \neq 2009$ & & \\
\hline 1980 vs 2013 & 1.171 & 3.737 & $p>0.5$ & $1980=2013$ & & \\
\hline 2013 vs 2009 & 3.451 & 3.737 & $p<0.05$ & $2013 \neq 2009$ & & \\
\hline \multicolumn{7}{|l|}{ ANOVA--All Features } \\
\hline Source of Variation & SS & $d f$ & MS & $F$ & P-value & F crit \\
\hline Between Groups & 111.1 & 3 & 37.04 & 7.945 & $2.9778 \mathrm{E}-05$ & 2.612 \\
\hline Within Groups & 5833.1 & 1252 & 4.66 & & & \\
\hline Total & 5944.2 & 1255 & & & & \\
\hline \multicolumn{7}{|c|}{ Tukey Post Hoc Comparison } \\
\hline Comparison & $q$ & $q, 0.05, \infty, 3$ & $p$ & Conclusion & & \\
\hline 1956 vs 2009 & 6.166 & 3.633 & $p<0.001$ & $1956 \neq 2009$ & & \\
\hline 1956 vs 2013 & 5.08 & 3.663 & $\mathrm{p}<0.005$ & $1956 \neq 2013$ & & \\
\hline 1956 vs 1980 & 2.404 & 3.663 & $\mathrm{p}>0.1$ & $1956=1980$ & & \\
\hline 1980 vs 2009 & 4.049 & 3.633 & $p<0.01$ & $1980 \neq 2009$ & & \\
\hline 1980 vs 2013 & 3.103 & 3.663 & $p>0.1$ & $1980=2013$ & & \\
\hline 2013 vs 2009 & 0.359 & 3.633 & $p>0.05$ & $2013=2009$ & & \\
\hline
\end{tabular}


Appendix 2

ANOVA Tables for 1956, 2009, 2013 Dataset 
Table A. ANOVA results for length of each off-channel habitat feature.

\begin{tabular}{|c|c|c|c|c|c|c|}
\hline \multicolumn{7}{|l|}{ ANOVA--Backwater } \\
\hline Source of Variation & SS & $d f$ & MS & $F$ & $P$-value & F crit \\
\hline Between Groups & 1579538.02 & 2 & 789769.0105 & 34.9451 & $1.78 \mathrm{E}-15$ & 3.0034 \\
\hline Within Groups & 26464954.3 & 1171 & 22600.3026 & & & \\
\hline Total & 28044492.3 & 1173 & & & & \\
\hline \multicolumn{7}{|c|}{ Tukey Post Hoc Comparison } \\
\hline Comparison & $q$ & $q, 0.05, \infty, 3$ & $p$ & Conclusion & & \\
\hline 1956 vs 2009 & 11.817 & 3.314 & $p<0.001$ & $1956 \neq 2009$ & & \\
\hline 1956 vs 2013 & 5.973 & 3.314 & $\mathrm{p}<0.001$ & $1956 \neq 2013$ & & \\
\hline 2013 vs 2009 & 5.073 & 3.314 & $p<0.001$ & $2013 \neq 2009$ & & \\
\hline \multicolumn{7}{|l|}{ ANOVA--Side Channel } \\
\hline Source of Variation & SS & $d f$ & MS & $F$ & $P$-value & F crit \\
\hline Between Groups & 3896327.39 & 2 & 1948163.694 & 8.5391 & 0.0003 & 3.0556 \\
\hline Within Groups & 34678184.5 & 152 & 228145.9507 & & & \\
\hline Total & 38574511.9 & 154 & & & & \\
\hline \multicolumn{7}{|c|}{ Tukey Post Hoc Comparison } \\
\hline Comparison & $q$ & $q, 0.05, \infty, 3$ & $p$ & Conclusion & & \\
\hline 1956 vs 2009 & 5.783 & 3.314 & $p<0.001$ & $1956 \neq 2009$ & & \\
\hline 1956 vs 2013 & 4.01 & 3.314 & $p<0.05$ & $1956 \neq 2013$ & & \\
\hline 2013 vs 2009 & 0.268 & 3.314 & $\mathrm{p}>0.5$ & $2013=2009$ & & \\
\hline \multicolumn{7}{|l|}{ ANOVA--Other Channel } \\
\hline Source of Variation & SS & $d f$ & $M S$ & $F$ & $P$-value & F crit \\
\hline Between Groups & 9548165.96 & 2 & 4774082.978 & 30.6688 & $2.18 \mathrm{E}-13$ & 3.0112 \\
\hline Within Groups & 90441937.7 & 581 & 155665.9857 & & & \\
\hline Total & 99990103.7 & 583 & & & & \\
\hline \multicolumn{7}{|c|}{ Tukey Post Hoc Comparison } \\
\hline Comparison & $q$ & $q, 0.05, \infty, 3$ & $p$ & Conclusion & & \\
\hline 1956 vs 2009 & 10.501 & 3.314 & $p<0.001$ & $1956 \neq 2009$ & & \\
\hline 1956 vs 2013 & 2.498 & 3.314 & $0.20>p>0.10$ & $1956=2013$ & & \\
\hline 2013 vs 2009 & 6.116 & 3.314 & $p<0.001$ & $2013 \neq 2009$ & & \\
\hline \multicolumn{7}{|l|}{ ANOVA--All Features } \\
\hline Source of Variation & SS & $d f$ & MS & $F$ & P-value & F crit \\
\hline Between Groups & 4952208 & 2 & 2476103.907 & 20.8697 & $1.08 \mathrm{E}-09$ & 3.0004 \\
\hline Within Groups & 226613987 & 1910 & 118646.0667 & & & \\
\hline Total & 231566195 & 1912 & & & & \\
\hline \multicolumn{7}{|c|}{ Tukey Post Hoc Comparison } \\
\hline Comparison & $q$ & $q, 0.05, \infty, 3$ & $p$ & Conclusion & & \\
\hline 1956 vs 2009 & 8.7818 & 3.314 & $p<0.001$ & $1956 \neq 2009$ & & \\
\hline 1956 vs 2013 & 6.88 & 3.314 & $p<0.001$ & $1956 \neq 2013$ & & \\
\hline 2013 vs 2009 & 0.5621 & 3.314 & $p>0.5$ & $2013=2009$ & & \\
\hline
\end{tabular}


Table B. ANOVA results for perimeter of each off-channel habitat feature.

\begin{tabular}{|c|c|c|c|c|c|c|}
\hline \multicolumn{7}{|l|}{ ANOVA--Backwater } \\
\hline Source of Variation & SS & $d f$ & MS & $F$ & P-value & F crit \\
\hline Between Groups & 8267315 & 2 & 4133657.592 & 30.9627 & $7.88 \mathrm{E}-14$ & 3.0034 \\
\hline Within Groups & $1.56 \mathrm{E}+08$ & 1171 & 133504.2365 & & & \\
\hline Total & $1.65 E+08$ & 1173 & & & & \\
\hline \multicolumn{7}{|c|}{ Tukey Post Hoc Comparison } \\
\hline Comparison & $q$ & $q, 0.05, \infty, 3$ & $p$ & Conclusion & & \\
\hline 1956 vs 2009 & 11.1268 & 3.314 & $p<0.001$ & $1956 \neq 2009$ & & \\
\hline 1956 vs 2013 & 6.2022 & 3.314 & $p<0.001$ & $1956 \neq 2013$ & & \\
\hline 2013 vs 2009 & 4.1442 & 3.314 & $p<0.01$ & $2013 \neq 2009$ & & \\
\hline & & & & & & \\
\hline \multicolumn{7}{|l|}{ ANOVA--Side Channel } \\
\hline Source of Variation & SS & $d f$ & MS & $F$ & $P$-value & F crit \\
\hline Between Groups & 24377106 & 2 & 12188552.76 & 7.7277 & 0.0006 & 3.0556 \\
\hline Within Groups & $2.4 \mathrm{E}+08$ & 152 & 1577244.781 & & & \\
\hline Total & $2.64 \mathrm{E}+08$ & 154 & & & & \\
\hline \multicolumn{7}{|c|}{ Tukey Post Hoc Comparison } \\
\hline Comparison & $q$ & $q, 0.05, \infty, 3$ & $p$ & Conclusion & & \\
\hline 1956 vs 2013 & 5.6088 & 3.314 & $p<0.001$ & $1956 \neq 2013$ & & \\
\hline 1956 vs 2009 & 3.9725 & 3.314 & $p<0.025$ & $1956 \neq 2009$ & & \\
\hline 2009 vs 2013 & 0.1602 & 3.314 & $p>0.5$ & $2009=2013$ & & \\
\hline \multicolumn{7}{|l|}{ ANOVA--Other Channel } \\
\hline Source of Variation & SS & $d f$ & MS & $F$ & $P$-value & F crit \\
\hline Between Groups & 49270537 & 2 & 24635268.47 & 21.5982 & $8.96 \mathrm{E}-10$ & 3.0112 \\
\hline Within Groups & $6.63 E+08$ & 581 & 1140616.211 & & & \\
\hline Total & $7.12 E+08$ & 583 & & & & \\
\hline \multicolumn{7}{|c|}{ Tukey Post Hoc Comparison } \\
\hline Comparison & $q$ & $q, 0.05, \infty, 3$ & $p$ & Conclusion & & \\
\hline 1956 vs 2009 & 9.1233 & 3.314 & $p<0.001$ & $1956 \neq 2009$ & & \\
\hline 1956 vs 2013 & 3.2669 & 3.314 & $0.10>p>0.05$ & $1956=2013$ & & \\
\hline 2013 vs 2009 & 4.0693 & 3.314 & $p<0.001$ & $2013 \neq 2009$ & & \\
\hline \multicolumn{7}{|l|}{ ANOVA--All Features } \\
\hline Source of Variation & SS & $d f$ & MS & $F$ & $P$-value & F crit \\
\hline Between Groups & 28690184 & 2 & 14345092.09 & 17.7363 & $2.33 \mathrm{E}-08$ & 3.0004 \\
\hline Within Groups & $1.54 \mathrm{E}+09$ & 1910 & 808799.6099 & & & \\
\hline Total & $1.57 \mathrm{E}+09$ & 1912 & & & & \\
\hline \multicolumn{7}{|c|}{ Tukey Post Hoc Comparison } \\
\hline Comparison & $q$ & $q, 0.05, \infty, 3$ & $p$ & Conclusion & & \\
\hline 1956 vs 2013 & 7.2746 & 3.314 & $p<0.001$ & $1956 \neq 2013$ & & \\
\hline 1956 vs 2009 & 7.5091 & 3.314 & $p<0.001$ & $1956 \neq 2009$ & & \\
\hline 2009 vs 2013 & 1.0801 & 3.314 & $p>0.5$ & $2009=2013$ & & \\
\hline
\end{tabular}


Table C. ANOVA results for area of each off-channel habitat feature.

\begin{tabular}{|c|c|c|c|c|c|c|}
\hline \multicolumn{7}{|l|}{ ANOVA--Backwater } \\
\hline Source of Variation & SS & $d f$ & MS & $F$ & $P$-value & F crit \\
\hline Between Groups & 19.8833 & 2 & 9.9416 & 33.4421 & $7.55 \mathrm{E}-15$ & 3.0034 \\
\hline Within Groups & 348.1133 & 1171 & 0.2973 & & & \\
\hline Total & 367.9966 & 1173 & & & & \\
\hline \multicolumn{7}{|c|}{ Tukey Post Hoc Comparison } \\
\hline Comparison & $q$ & $q, 0.05, \infty, 3$ & $p$ & Conclusion & & \\
\hline 1956 vs 2009 & 11.5339 & 3.314 & $\mathrm{p}<0.001$ & $1956 \neq 2009$ & & \\
\hline 1956 vs 2013 & 6.3673 & 3.314 & $\mathrm{p}<0.001$ & $1956 \neq 2013$ & & \\
\hline 2013 vs 2009 & 4.3621 & 3.314 & $p<0.01$ & $2013 \neq 2009$ & & \\
\hline \multicolumn{7}{|l|}{ ANOVA--Side Channel } \\
\hline Source of Variation & SS & $d f$ & MS & $F$ & $P$-value & F crit \\
\hline Between Groups & 113.911 & 2 & 56.9555 & 15.2606 & $9.13 \mathrm{E}-07$ & 3.0556 \\
\hline Within Groups & 567.2944 & 152 & 3.7322 & & & \\
\hline Total & 681.2054 & 154 & & & & \\
\hline \multicolumn{7}{|c|}{ Tukey Post Hoc Comparison } \\
\hline Comparison & $q$ & $q, 0.05, \infty, 3$ & $p$ & Conclusion & & \\
\hline 1956 vs 2009 & 7.7836 & 3.314 & $\mathrm{p}<0.001$ & $1956 \neq 2009$ & & \\
\hline 1956 vs 2013 & 5.1098 & 3.314 & $\mathrm{p}<0.001$ & $1956 \neq 2013$ & & \\
\hline 2013 vs 2009 & 0.7047 & 3.314 & $p>0.5$ & $2013=2009$ & & \\
\hline \multicolumn{7}{|c|}{ ANOVA--Other Channel } \\
\hline Source of Variation & SS & $d f$ & MS & $F$ & $P$-value & F crit \\
\hline Between Groups & 457.8237 & 2 & 228.9118 & 28.1661 & $2.11 \mathrm{E}-12$ & 3.0112 \\
\hline Within Groups & 4721.911 & 581 & 8.1272 & & & \\
\hline Total & 5179.735 & 583 & & & & \\
\hline \multicolumn{7}{|c|}{ Tukey Post Hoc Comparison } \\
\hline Comparison & $q$ & $q, 0.05, \infty, 3$ & $p$ & Conclusion & & \\
\hline 1956 vs 2009 & 10.4282 & 3.314 & $\mathrm{p}<0.001$ & $1956 \neq 2009$ & & \\
\hline 1956 vs 2013 & 3.8986 & 3.314 & $\mathrm{p}<0.025$ & $1956 \neq 2013$ & & \\
\hline 2013 vs 2009 & 4.4635 & 3.314 & $\mathrm{p}<0.001$ & $2013 \neq 2009$ & & \\
\hline \multicolumn{7}{|l|}{ ANOVA--All Features } \\
\hline Source of Variation & SS & $d f$ & MS & $F$ & $P$-value & F crit \\
\hline Between Groups & 210.2084 & 2 & 105.1042 & 28.0016 & $1.03 \mathrm{E}-12$ & 3.0004 \\
\hline Within Groups & 7169.2087 & 1910 & 3.7535 & & & \\
\hline Total & 7379.4171 & 1912 & & & & \\
\hline \multicolumn{7}{|c|}{ Tukey Post Hoc Comparison } \\
\hline Comparison & $q$ & $q, 0.05, \infty, 3$ & $p$ & Conclusion & & \\
\hline 1956 vs 2009 & 10.3314 & 3.314 & $p<0.001$ & $1956 \neq 2009$ & & \\
\hline 1956 vs 2013 & 7.4408 & 3.314 & $\mathrm{p}<0.001$ & $1956 \neq 2013$ & & \\
\hline 2013 vs 2009 & 1.3906 & 3.314 & $p>0.5$ & $2013=2009$ & & \\
\hline
\end{tabular}

